Emmett, Bridget A.; Cooper, David; Smart, Simon; Jackson, Bethanna; Thomas, Amy; Cosby, Bernard; Evans, Chris; Glanville, Helen; McDonald, James E.; Malham, Shelagh K.; Marshall, Miles; Jarvis, Susan; Rajko-Nenow, Paulina; Webb, Gearoid P.; Ward, Sue; Rowe, Ed; Jones, Laurence; Vanbergen, Adam J. (D; Keith, Aidan; Carter, Heather; Pereira, M. Glória; Hughes, Steve; Lebron, Inma; Wade, Andrew; Jones, David L.. 2016. Spatial patterns and environmental constraints on ecosystem services at a catchment scale. Science of the Total Environment, 572. 1586-1600.

https://doi.org/10.1016/j.scitotenv.2016.04.004

(C) 2016 Elsevier B.V.

This manuscript version is made available under the CC-BY-NC-ND 4.0 license http://creativecommons.org/licenses/by-nc-nd/4.0/ (cc) EY-NG-ND

This version available http://nora.nerc.ac.uk/id/eprint/516342/

NERC has developed NORA to enable users to access research outputs wholly or partially funded by NERC. Copyright and other rights for material on this site are retained by the rights owners. Users should read the terms and conditions of use of this material at http://nora.nerc.ac.uk/policies.html\#access

NOTICE: this is the author's version of a work that was accepted for publication in Science of the Total Environment. Changes resulting from the publishing process, such as peer review, editing, corrections, structural formatting, and other quality control mechanisms may not be reflected in this document. Changes may have been made to this work since it was submitted for publication. A definitive version was subsequently published in Science of the Total Environment, 572. 1586-1600. https://doi.org/10.1016/j.scitotenv.2016.04.004 


\title{
Spatial patterns and environmental constraints on ecosystem services at a catchment scale
}

\author{
Bridget A Emmett ${ }^{1 *}$, David Cooper ${ }^{1}$, Simon Smart ${ }^{2}$, Bethanna Jackson ${ }^{3}$, Amy Thomas ${ }^{1}$, Bernard \\ Cosby $^{1}$, Chris Evans ${ }^{1}$, Helen Glanville ${ }^{4}$, James E McDonald ${ }^{4}$, Shelagh K Malham ${ }^{5,9}$, Miles Marshall, \\ Susan Jarvis ${ }^{2}$, Paulina Rajko-Nenow ${ }^{5}$, Gearoid P Webb ${ }^{6}$, Sue Ward ${ }^{2}$, Ed Rowe ${ }^{1}$, Laurence Jones ${ }^{1}$, \\ Adam J Vanbergen ${ }^{7}$, Aidan Keith ${ }^{2}$, Heather Carter ${ }^{2}$, M. Glória Pereira ${ }^{2}$, Steve Hughes ${ }^{1}$, Inma \\ Robinson ${ }^{1}$, Andrew Wade ${ }^{11}$ and David L Jones ${ }^{8}$. \\ ${ }^{1}$ Centre for Ecology and Hydrology, Environment Centre Wales, Deiniol Rd, Bangor LL57 2UW, UK \\ ${ }^{2}$ Centre for Ecology and Hydrology, Lancaster Environment Centre, Lancaster, Bailrigg LA1 4AP, UK \\ ${ }^{3}$ School of Geography, Environment and Earth Sciences, Victoria University of Wellington, New \\ Zealand
}

${ }^{4}$ School of Biological Sciences, Bangor University, Bangor, Gwynedd, LL57 2UW, UK

${ }^{5}$ School of Ocean Sciences, Bangor University, Menai Bridge, Anglesey, LL59 5AB, UK

${ }^{6}$ Centre for Ecology and Hydrology, MacLean Bldg, Benson Ln, Crowmarsh Gifford, Wallingford, Oxfordshire OX10 8BB, UK

${ }^{7}$ Centre for Ecology and Hydrology, Bush Estate, Penicuik, Edinburgh, EH26 OQB, UK

${ }^{8}$ School of Environment, Natural Resources and Geography, Bangor University, Bangor, Gwynedd, LL57 2UW, UK

${ }^{9}$ Centre for Applied Marine Sciences, Bangor University, Menai Bridge, Anglesey, LL59 5AB, UK

${ }^{10}$ Lancaster University, Lancaster Environment Centre, Lancaster, Bailrigg LA1 4YQ, UK

${ }^{11}$ Dept of Geography, University of Reading, Whiteknights, PO BOX 227 Reading RG6 6AB, UK

*Corresponding Author. Email address: bae@ceh.ac.uk

\begin{abstract}
Improved understanding and prediction of the fundamental environmental controls on ecosystem service supply across the landscape will help to inform decisions made by policy makers and landwater managers. To evaluate this issue for a local catchment case study, we explored metrics and spatial patterns of service supply for water quality regulation, agriculture production, carbon storage, and biodiversity for the Macronutrient Conwy catchment. Methods included using ecosystem models such as LUCI and JULES, integration of national scale field survey datasets, earth observation products and plant trait databases, to produce finely resolved maps of species richness and primary production. Analyses were done with both $1 \times 1 \mathrm{~km}$ gridded and subcatchment data. A common single gradient characterised catchment scale ecosystem services supply with agricultural production and carbon storage at opposing ends of the gradient as reported for a national-scale
\end{abstract}


assessment. Species diversity was positively related to production due to the below national average productivity levels in the Conwy combined with the unimodal relationship between biodiversity and productivity at the national scale. In contrast to the national scale assessment, a strong reduction in water quality as production increased was observed in these low productive systems. Various soil variables were tested for their predictive power of ecosystem service supply. Soil carbon, nitrogen, their ratio and soil $\mathrm{pH}$ all had double the power of rainfall and altitude, each explaining around $45 \%$ of variation but soil $\mathrm{pH}$ is proposed as a potential metric for ecosystem service supply potential as it

is a simple and practical metric which can be carried out in the field with crowd-sourcing technologies now available. The study emphasises the importance of considering multiple ecosystem services together due to the complexity of covariation at local and national scales, and the benefits of exploiting a wide range of metrics for each service to enhance data robustness.

Keywords: macronutrients; productivity, biodiversity, carbon, water quality, soil pH

\section{Introduction}

Increasing pressures on our natural resources and evidence of depletion of our Natural Capital and the services they deliver (e.g. the Millennium Ecosystem Assessment (Reid, 2005); the UK National Ecosystem Assessment (Morris and Camino, 2011)) has led in recent years to a refocus of catchment research and management to consider a wide range of ecosystem services (ES) and how these are influenced by processes in the catchment. Land managers within catchments must now aim to deliver a range of regulating, provisioning and cultural ecosystem services. Inevitably, this increased management complexity will result in trade-offs as attempts to maximise one service may incur the loss or degradation of other services (Gibbons et al., 2014). Meeting these challenges requires improved understanding of the fundamental environmental constraints on ecosystem services and functions, and their distributions and interactions at a landscape scale (Bennett et al., 2009; Raudsepp-Hearne et al., 2010).

Among the major policy concerns related to catchment management, four environmental issues are particularly relevant: sustainable production; biodiversity protection; water security; and climate change mitigation. In complex ecosystems these issues are tightly coupled and practices intended to improve one can be expected to impact the others for better or worse. To further complicate matters, there are a number of ES metrics related to each of the four issues, and some commonly measured ES variables may relate to more than one issue. Setting policy or management plans to minimize trade-offs and maximize co-benefits in these systems requires a quantitative understanding of the inter-relationships of the various ES metrics and their responses to change in ecosystem function. Understanding the inter-relationships among the many relevant ES metrics, in turn, requires robust data that can be analysed using e.g. multi-variate techniques to reduce the dimensionality of the problem and present a conceptually simpler summary of the important interactions.

For example, in a national-scale analysis for Great Britain (GB), Maskell et al. (2013) estimated the relationships among metrics of ecosystem service delivery. Using principal components and 
redundancy analyses they identified a single productivity gradient that could be used to characterise the delivery of many ecosystem services, with carbon storage and primary productivity maximised at opposing ends of the gradient. There was a well-defined response curve for each ecosystem service metric along this gradient, with the biodiversity and water quality response curves peaking near the centre of the gradient. They concluded that, under present GB conditions, neither high productivity nor high carbon storage favour biodiversity and water quality, so that under the concept of landsharing and land-sparing (Green et al., 2005), a land-sharing approach could be appropriate for biodiversity and water quality while land-sparing would favour carbon storage and production.

However, scale is a fundamental attribute of ecosystem services, affecting both the perceived effectiveness of service provision and the metrics available to quantify the service delivery. Mapping or developing multi-variate summaries of ecosystem services essentially aggregates complex information (Burkhard et al., 2012). These visualizations of ES relationships can provide decision makers with a powerful decision support tool for large-scale management (Swetnam et al., 2010), but there is often a lack of information relevant to local-scale decision making (Turner and Daily, 2008). While there have been a few empirical studies of multi-scale relationships among ES, these have generally been limited to pairwise ES relationships (e.g., species richness and net primary production (Costanza et al., 2007)). Analyses of the scale dependence of the inter-relationships among multiple ES are less common, either because the quantity and quality of data needed for robust multi-variate analyses usually are only available at a single, national scale, or the questions being asked relate only to national scale policy or planning.

Here we explore the issue of scale dependence of multiple ES provision at a scale relevant for local decision making, the catchment. Our case study catchment is the Conwy in North Wales, UK, which has a wide range of climate, topography, soil and landcover types, and is currently the subject of a number of intensive research including the NERC Macronutrient Programme (Whitehead and Crossman, 2012). Using the available range of empirical and modelled data for the Conwy, we examine metrics and spatial patterns of ES supply related to four important local issues: water quality regulation, agriculture production, carbon storage and sequestration potential, and biodiversity maintenance. We address the issue of scale dependence of multiple ES provision in two ways. First, within the Conwy, given the dendritic nature of the drainage, we can compare results derived on a uniform $1 \times 1 \mathrm{~km}$ grid with results derived from 71 subcatchments ranging in size from 1 to $10 \mathrm{~km}^{2}$. Second, given the range of land uses in the Conwy which place the catchment at a low to intermediate position on the national productivity gradient of Maskell et al. (2013), we can compare the results from with the Conwy with the national scale results for the GB (Maskell et. al., 2013).

Questions of scale aside, the possibility that inter-relationships among multiple ES provision can be organised along a single productivity gradient ultimately depends on having adequate and robust metrics for productivity. In this work we consider four measures of productivity, two related to the supporting service of primary production and two related to the provisioning service of agricultural production. These are respectively: above-ground NPP (ANPP) using a plant-trait based model based on field measurements over a range of habitats; 2) net above- and below-ground primary productivity (NPP) from the JULES earth system model; 3) agricultural potential estimated from landscape properties using the LUCl ecosystem services model; and 4) agricultural production using direct records of livestock numbers in the catchment. All of these involve different scales of resolution and require different input data sets. 
As a general hypothesis we pose that the provision of ES services at the catchment scale can be organized along a single gradient with agricultural production and carbon storage defining the end members as observed at the national scale. We further suppose that this pattern will be robust within the catchment whether the ES metrics are analysed on $1 \times 1$ gridded basis vs a subcatchment basis. We conjecture that the pattern of ES provision related to productivity will be similar to the observed national pattern in the UK, when the range corrected for the range of productivity in the Conwy catchment and that the availability of macronutrients will have high predictive power of ecosystem service supply. To test these hypotheses, the goals of this research were:

1. To quantify and map ES metrics in the Conwy catchment for four key environmental issues related to catchment management: productivity, water quality, carbon storage and biodiversity.

2. To determine if a single gradient can be used to characterise the supply of several ES within the Conwy with agricultural production and carbon storage at opposing ends of the gradient (a catchment scale pattern conceptually similar to the pattern reported for the nationalscale GB assessment).

3. To determine the scale dependence of ES relationships with the Conwy catchment by comparing multiple ES gradients derived using both $1 \times 1 \mathrm{~km}$ gridded data vs subcatchment data.

4. To compare the relative positions of individual ES maxima on this single gradient with those from the national assessment correcting for the lower magnitude and range of productivity observed in the Conwy.

5. To test the ability of macronutrient availability to predict this gradient and therefore ES supply.

\section{Materials and Methods}

\subsection{Site Description}

The Conwy catchment in North Wales is predominantly rural and agricultural, but with significant areas of woodland. Catchment characteristics, land use and climate are strongly influenced by the large altitudinal range from sea level to over $1000 \mathrm{~m}$ within a distance of less than $10 \mathrm{~km}$. Mean annual air temperature in the Conwy is 10 degrees C. Higher elevations support low intensity sheep rearing on moorland and blanket bog. Lower land supports mixed dairy, beef and sheep farming, with little arable land present. In addition to coniferous plantation forestry, there is scattered seminatural woodland in the lower lying part of the catchment including ecologically important areas of wet woodland (Figure 1). (See Appendix A in Supplementary Material for more details on the Conwy catchment).

The four key catchment characteristics which are considered likely drivers of the ecosystem services we are considering have complex spatial distributions (Figure 2). Elevations are derived from the CEH $50 \mathrm{~m}$ DTM (https://www.ceh.ac.uk/services/information-products). Precipitation values are $1 \mathrm{~km}$

SAAR (standard-period annual average rainfall) values based on 30-year average 1961-1990 data from the UK Met Office (http://nrfa.ceh.ac.uk/rainfall-statistics) and range from 500 to $3500 \mathrm{~mm}$ per year. Elevation and location with respect to prevailing weather, both independent of ecosystem 
services, largely account for the strong precipitation gradient from south and west to north and east. The land cover types shown are those of the CEH Landcover Map (http://www.ceh.ac.uk/services/land-cover-map-2007; referred to subsequently as LCM 2007). The soil classification is from the National Soil Map of England and Wales (NATMAP; http://www.landis.org.uk/data/natmap.cfm; referred to subsequently as NATMAP). Soils are largely characteristic of upland Wales, but with a relatively high proportional cover of upland acidic organic soils, notably in the south of the catchment where drainage is poor. While soils evolve over decades or longer in association with vegetation, for present purposes, they are considered as fixed, and as potential drivers of ecosystem services.

\subsection{Land-based vs water-based metrics}

The supply of four ecosystem services were selected for analysis due to their strong alignment with national policy priorities in Wales: agricultural production, regulation of water quality, regulation of climate through carbon storage and emissions and maintenance of biodiversity. The catchment-wide spatial distribution of each ecosystem service metric is estimated by relating it to continuous spatial data using explanatory catchment characteristic and climate variables. The relationship may be an existing model, or a new model derived by relating point measurements of the metric to continuous spatial data values. The existing or new model is then used to estimate the value of the metric over the whole catchment.

Metrics for the ecosystem services we are considering fall naturally into two categories: land surface and stream water. Values of land surface metrics generally have no clear direct link with values at a distance. They represent local conditions in the immediate vicinity of the measurement site. In contrast, stream water metrics may be largely unrelated to conditions in the immediate vicinity, being representative of conditions over a wider catchment area. Groundwater measurements from boreholes represent an intermediate type, but are not considered here.

This distinction leads to differences in the natural way of representing point values of metrics as a function of explanatory variables. For land surface metrics a model will be sought relating the metric to local values, while for stream water variables it is more appropriate to use a catchment-wide aggregated measure of the explanatory variables. Once a model has been selected, spatially continuous estimates of land surface metrics can be directly derived from spatially continuous explanatory variables. Often the spatially continuous explanatory variables will themselves be available only on a grid, so that simulation of land surface metrics will be most appropriate on the same grid.

For stream water metrics, the relationship derived from aggregated explanatory variables is likely to depend on the selection of locations and the size of the upstream catchments. It is also clear that sites need to have some measure of independence, since two locations on the same reach of a river are likely to have very similar metric values and upstream aggregate catchment characteristics. We have used water quality data from 71 independent subcatchments representing the range of land uses present in the Conwy catchment, each subcatchment having area of the order of 1-10 km². Four key land use types have previously been identified (Cooper et al., 2014; Evans et al., 2010), namely mountain, peat, forest and agriculture. Each of these classes is well-represented in the 71 subcatchments. Any model of water quality as a function of upstream catchment characteristics at these sites then strictly only applies, under extrapolation, to other stream water sites of a similar 
dimension to those sampled. The model cannot be applied as it stands to give a spatially continuous measure of stream water metrics. However, notional estimates may be derived over a continuous grid having similar dimensions to the catchments used to estimate a stream water metric relationship. The simulations generated on this grid will then approximate the stream water metric which would be measured from each grid square in isolation.

To reflect the differences in the land surface and stream water metrics, we have used both a grid based (most natural for land surface metrics) and a catchment-based (most natural for stream water metrics) approach to spatially estimating ecosystem service metrics. For the grid-based approach we use a $1 \mathrm{~km}^{2}$ cell, taking either the dominant or mean value of the explanatory variable within the grid cell. Land surface metric estimates for the 71 subcatchments are found by taking a mean of estimates over those grid squares present in the subcatchment.

\subsection{Production metrics}

We estimate potential of production supply using four metrics of which two metrics relate to the supporting service of primary production and two metrics to the provisioning service of agricultural production. These are respectively: net above- and below-ground primary productivity (NPP) from the JULES model; above-ground NPP (ANPP) using a plant-trait based model based on field measurements over a range of habitats; agricultural potential estimated from landscape properties using the LUCI model; and agricultural production using direct records of livestock numbers in the catchment. These four approaches do not all aim to simulate the same variable, but each gives an estimate of some measure of vegetative, and thus (in a predominantly livestock area) potential agricultural, production. Estimates of the four metrics have not all been made for the same year, but we expect inter-year variability to be small compared to spatial variability in these metrics in the Conwy catchment.

\subsubsection{ANPP estimated from a Plant-trait approach}

We used an empirical model to predict above-ground NPP (ANPP; g dry mass $\mathrm{m}^{-2} \mathrm{yr}^{-1}$ of above ground biomass) given the plant species composition and species abundance. Note that these units differ from JULES but can be roughly compared assuming that $50 \%$ of primary production is below ground and $50 \%$ of dry mass is carbon. This is a strong assumption and the true split is likely to differ by plant functional type (Mokany et al., 2006). A statistical model was developed using a dataset of ANPP measurements based on peak growing season biomass harvests from $1 \mathrm{~m}^{2}$ plots located within a wide range of habitat types covering the majority of the ANPP gradient across Britain from peatlands through to intensively managed lowland grasslands. Three explanatory variables were tested to produce the best-fitting statistical model predicting ANPP. The three variables were all derived from the vascular plant species composition of each sample plot and comprised coverweighted Specific Leaf Area (SLA), the Shannon-Wiener diversity index and species richness.

Cover-weighted SLA is a fundamental trait that tracks a major axis of plant specialisation in response to variation in nutrient availability (Reich, 2014; Wright et al., 2004). High SLA plant species have high relative growth rates and are found in more productive habitats. Low SLA species are slower growing, have higher leaf longevity and a greater proportion of cell wall to cell lumen and hence have lower leaf $\mathrm{N}$ per unit mass. Weighting mean SLA for a vegetation stand by cover of the plants present ensures sensitivity to the relative abundance of the species present (Grime, 1998; Laughlin, 
2011). Abundance-weighted SLA has been shown to be a robust predictor of above-ground biomass production and plant growth rate (Garnier et al., 2004; Vile et al., 2006). Species richness and the Shannon-Wiener index were tested for their ability to explain further residual variation having accounted for the main effect of variation in SLA. This is consistent with a number of mechanisms that vary in their importance along the productivity gradient but all are hypothesised to result in an augmentation of primary production where species richness is higher (Cardinale et al., 2011).

We fitted a Bayesian random intercepts model written in OpenBUGS (Lunn et al., 2012). Outlying points were identified using the method of Ntzoufras (2011). All three explanatory variables were fitted to observed ANPP and In(ANPP). We used explanatory variables centred and standardised to zero mean and unit standard deviation to reduce correlation between intercept and slopes. Models were fitted with and without a residual random intercept for each site or habitat in order to determine how much between-habitat variation was not explained by the three selected predictors. (See Appendix B in Supplementary Material for further details).

The best fitting model comprised cover weighted SLA and the Shannon diversity index. We used this model to estimate above-ground ANPP for terrestrial habitats in the Conwy catchment. The coverweighted SLA and diversity of plots was calculated for the plots used for estimation of plant diversity in the catchment. A linkage between SLA, diversity and land cover was provided by a model derived from $1 \mathrm{~m}^{2}$ quadrat values in the representative Countryside Survey dataset (Norton et al., 2012; Smart et al., 2002). Through this linkage a mean predicted ANPP was calculated for each $1 \mathrm{~km}^{2}$ grid square using LCM 2007 land cover.

\subsubsection{NPP derived from the JULES model}

JULES (Joint UK Land Environment Simulator) (Best et al., 2011; Clark et al., 2011) is a process-based Dynamic Global Vegetation Model that simulates the fluxes of carbon, water and energy between the atmosphere and the land surface at a point. The model is used to generate an independent estimate of combined above- and below-ground NPP $\left(\mathrm{g} \mathrm{C} \mathrm{m}^{-2}\right)$ for each 1-km square of the catchment. We used a configuration of JULES version 2.2 including a two-stream, multilayer model of radiation interception by the canopy, with photosynthesis calculated separately for sunlit and shaded leaves.

Estimates of NPP are made using JULES internal relationships between NPP and environmental variables, without reference to measured field values in the Conwy catchment. Many of the standard JULES inputs and parameters have been calculated for model applications in England and Wales for recent decades, at a $1 \mathrm{~km}^{2}$ grid scale, and are included in the CHESS dataset (Robinson et al., 2015). We used hourly CHESS meteorological estimates for the year 2000 for the Conwy catchment to derive an annual NPP value for each grid square. The fraction of each land cover type in a 1-km square was estimated by translating LCM 2007 class into one of the five plant functional types (broadleaf tree, needleleaf tree, C3 grass, C4 grass, shrubs) used in the JULES model. The model uses soil hydrological and thermal properties to characterise energy and water balance, and we have used previously derived estimates of these for each of the NATMAP soil types shown in Figure 2, taking estimates for the dominant soil type in each 1-km square. 


\subsubsection{Agricultural potential derived from the LUCI model}

The LUCI model, building on the Polyscape model (Jackson et al., 2013), estimates agricultural potential as a function of slope, aspect, soil hydraulic properties, soil fertility, and climatic variables. The methodology is described in more detail by Jackson et al. (2013). The model was previously parametrised at a site in upland mid-Wales, and is applied to the Conwy catchment using known values of spatially continuous explanatory variables. LUCI classifies agricultural potential on a scale from 1 to 5, moving from very high to very low potential. Estimates on the $1 \mathrm{~km}^{2}$ grid were derived using CHESS data for the year 2000 for comparability with JULES estimates.

\subsubsection{Livestock density as surrogate for productivity}

We estimated livestock density from the 2011 UK Government Department for Environment, Food and Rural Affairs (Defra) June agricultural survey data. The survey provides estimates of agricultural variables for standard "small areas" based on aggregated parishes. For the Conwy catchment most of the land area upstream of the tidal limit of the main river constitutes a single small area under the Defra definition. Four other small areas drain to the estuary directly. Edinburgh University Data Library (EDINA; http://edina.ac.uk/agcensus/) has developed algorithms which convert the small area data into $1 \mathrm{~km}$ grid square estimates. This procedure uses a 7-fold land use classification (http://edina.ac.uk/agcensus/support/land use.shtml) to redistribute agricultural variables within small areas. This classification includes the standard agricultural grade classification together with woodland, urban, water and upland classes. For example, crops are distributed over agricultural land but sheep can also be distributed over hill land. All agriculture is excluded from urban and inland water. The $1 \mathrm{~km}$ data are aggregated to $2 \times 2 \mathrm{~km}$ squares for publication to preserve farmer confidentiality. These EDINA $2 \times 2 \mathrm{~km}$ square data have been used to estimate animal numbers by 1 $\mathrm{km}$ square in the Conwy catchment. A single measure of livestock numbers has been estimated from the June census figures, using weights of 1.0, 0.7 and 0.08 as weights respectively for dairy cows, beef cattle and sheep (http://archive.defra.gov.uk/foodfarm/farmmanage/advice/documents/defof-terms.pdf). Because the raw data are averaged over small areas, then modelled down to grid level, for regions within a single small area and having the same land classification animal densities will be precisely the same over large areas. This is apparent for sheep numbers through much of Snowdonia. The uncertainty inherent in these agricultural data means that data at less than grouped small area scale are only indicative of the true status of agriculture at $1 \mathrm{~km}^{2}$ scale.

\subsection{Carbon storage metrics}

Carbon stock data attributed to the soil and land cover combinations are from (Milne and Brown, 1997) and assigned by $5 \mathrm{~m}^{2}$ cell according to the dominant soil type, with land use aggregated into four categories; arable, wood, permanent grassland and semi-natural. It is assumed that all sites are at quasi-equilibrium soil carbon content and are under a stable climate; that similar soil and land use combinations across GB will have similar carbon content; and that sites are subject to "average" land management in the absence of more detailed information.

\subsection{Water quality metrics}

We used three types of water quality metric as indicators of the effectiveness of the water quality regulation ecosystem service: water chemistry, macroinvertebrate community composition and 
faecal indicator bacteria (FIB) counts. Nutrient concentrations can be indicators of poor biological health of streams, and the macroinvertebrate community is a more direct measure of this. Pathogenic faecal bacteria, apicomplexan protozoans and viruses represent a threat to human health (Thorn et al., 2011) and are discharged into rivers through pollution primarily occurring in areas with high numbers of livestock and point sources such as sewage treatment works and septic tanks (Malham et al., 2014).

Because not all water chemistry measurements are coincident in time, time-averaged values are used for each metric on the assumption that these are representative of medium-term time averages. The minimum sampling frequency for water chemistry data was quarterly for two years. These time averages are used directly for the catchment-based metric. For the grid-based metric, the catchment water quality values were regressed on upstream catchment characteristics, as proportions of landscape classifications (Cooper et al., 2014), providing an equation for use at $1 \mathrm{~km}$ grid scale to generate estimated values of the metric for each grid square. Where there are insufficient catchment values to provide an acceptable regression relationship, no grid water quality estimates are computed.

\subsubsection{Water chemistry}

The example water chemistry metrics we consider are concentrations of nitrate- $\mathrm{N}$ and dissolved organic carbon (DOC) in stream water. Samples were filtered in the field using $0.45 \mu \mathrm{m}$ Whatman cellulose nitrate membrane filters, and stored in polythene bottles at $4^{\circ} \mathrm{C}$ prior to chemical analysis. Nitrate-N concentrations were measured using a Dionex ICS-2000 ion chromatograph (http://onto.nerc.ac.uk/CAST/181.html). DOC was measured as non-purgeable organic carbon using a Shimadzu TOC-VCPH analyser (http://onto.nerc.ac.uk/CAST/164.html).

\subsubsection{Macroinvertebrate biology}

Macroinvertebrate samples were collected on a single occasion during autumn 2009-2011 at a subset of 30 of the 71 water quality monitoring sites. Sampling used a standard RIVPACS kick sampling method (Murphy and Weatherby, 2008; Murray-Bligh, 1999). Samples were preserved in the field using a $4 \%$ aqueous solution of formaldehyde. The samples were stored in clear plastic bags and further sealed within 1.3 litre screw topped plastic pots. Associated RIVPACS environmental variables were recorded at each site including stream width and depth, discharge category, substrate composition and a GPS location to later ascertain altitude, distance from source and slope (Murphy and Weatherby, 2008). Samples were processed in the laboratory, after first sorting according to the standard RIVPACS protocol. Invertebrates were identified to species level wherever possible. This was done using either 40x binocular microscopes or compound microscopes.

Database recording of the field and laboratory generated data was followed by data validation. Family level biological scores were generated from these data. These included BMWP (Biological Monitoring Working Party) and AWIC (Acid Water Indicator Community) scores, numbers of taxa and average scores per taxon (Armitage et al., 1983; Davy-Bowker et al., 2003; Davy-Bowker et al., 2005). The BMWP score is designed to detect eutrophication and is also considered an indicator of general degradation, with higher scores assigned to waters judged less polluted and of higher ecological status. 


\subsubsection{Faecal indicator bacteria (FIB)}

Stream water samples were analysed for E. coli and coliform counts at 16 sites in 2013-14, coinciding with water chemistry sampling. Water samples $(500 \mathrm{ml})$ were collected using a sterile polypropylene bottle (Nalgene) and delivered to the laboratory within 6 hours of collection. At each site approximately 16 samples were collected over the 2 year sampling period.

A subsample of stream water $(3 \mathrm{ml})$ was added to $27 \mathrm{ml}$ of Ringers solution and mixed by inversion. Thirty $\mathrm{ml}$ of diluted sample was passed through a $0.2 \mu \mathrm{m}$ Whatman cellulose nitrate membrane placed on a filter rig with vacuum pump. The filter membranes were aseptically transferred onto Harlequin ${ }^{\mathrm{TM}}$ E. coli/ coliform agar and plates were incubated at $37^{\circ} \mathrm{C}$ for $22 \pm 2$ hours. Subsequently $E$. coli and non-E.coli coliform colonies were counted from each plate and the results were expressed in cfu/ $30 \mathrm{ml}$ (colony-forming units/ $30 \mathrm{ml}$ ) with the limit of the detection (LOD) estimated as $10 \mathrm{cfu} /$ $30 \mathrm{ml}$. For presentation, values are converted to cfu/100ml. Each river water sample was tested in triplicate.

\subsection{Biodiversity metrics}

The Conwy catchment includes numerous designated areas of high biodiversity value (Special Areas for Conservation (SACS) and Sites of Special Scientific Interest (SSSIs)), amounting to $25 \%$ of the total catchment area. This indicates the perceived importance of biodiversity within the catchment. We focus on terrestrial diversity and use two metrics to estimate different aspects: plant species richness and habitat diversity. These are estimated as a function of broad habitat class, so that diversity within broad habitat is not accounted for.

\subsubsection{Plant species richness}

Estimates of species richness were required by vegetation type within the Conwy valley. Grid square estimates confound alpha with beta diversity and so obscure the extent to which species richness is a function of say a high diversity habitats with different species compositions or a small number of species rich habitats. Such confounding makes it impossible to meaningfully relate productivity to biodiversity to land management because all three properties vary among habitats (Huston 1999). Assembling fine-resolution estimates of within-habitat richness for an arbitrary small region of Britain is highly challenging. We developed a novel estimation procedure by integrating and downscaling statistically rigorous and representative sample-based field survey data with a remotely sensed census map of British habitats.

Vegetation data representative of each habitat in the Conwy catchment were extracted from the GB-wide Countryside Survey (CS) database. Species richness was based on counts in $4 \mathrm{~m}^{2}$ plots recorded in the 2007 survey. Plot types comprised random stratified and unenclosed habitat plots (see Norton et al. (2012) for further details on Countryside Survey methods). Plots were only selected where these were recorded in CS $1 \mathrm{~km}$ squares within the same ITE Land Classes and LCM2007 Broad Habitat class as those present in the Conwy catchment. The ITE Land Classification stratifies the British landscape by a complex of climatic, edaphic and topographic factors (Bunce et al., 1996). By selecting species data from equivalent habitats and land classes we ensured that these data represented species pools and plant species composition that will, as far as possible, reflect ecological conditions prevailing in the Conwy. 
Mean species richness was calculated for each LCM 2007 broad habitat class and then the mean value per $4 \mathrm{~m}^{2}$ per habitat value per habitat combined with the differing proportions of each habitat in each $1 \mathrm{~km}$ square in the Conwy to produce a map of mean plant species richness $\left(4 \mathrm{~m}^{2} \mathrm{~km}^{-2}\right)$ weighted by the extent of each habitat in each square. Thus the weighted mean richness is mapped as a single value for each $1 \mathrm{~km}$ square. Accompanying confidence intervals were calculated from an intercept-only mixed effects generalised linear model applied to species richness data for the CS quadrats located in each LCM2007 broad habitat class with an automatic correction for overdispersion as implemented using the proc glimmix procedure of the SAS statistical package (Littell et al., 2006). A log link function was applied to model the error distribution. Since CS vegetation plots are nested within $1 \mathrm{~km}$ survey squares and land classes, both factors were treated as random effects.

\subsubsection{Habitat diversity}

Habitat diversity was calculated as the number of dominant 1 ha LCM 2007 classes per $1 \mathrm{~km}^{2}$ grid square in the Conwy catchment, by overlaying LCM 2007 with the $1 \mathrm{~km}$ gridded outline map of the catchment.

\section{Results}

\subsection{Overview of ecosystem service metrics within the Conwy catchment}

An overview of the final estimates of the four different ecosystem services supply for the Conwy is presented in Table 1. The results highlight the wide range of supply within a catchment with such variable soil and land use types and in the case of agricultural production the variability in NPP and ANPP range associated with the plant trait SLA and JULES process modelling approaches. The results enable the Conwy to be placed within a wider national (and international) context and facilitates future comparative studies of catchment based service supply. The spatial structure of these data and interpretation of the final estimates are described for each service below.

\subsection{Production}

The spatial distribution of the production metrics given by the four methods is shown in Figure 3 . The spatial distribution of JULES NPP estimates identifies the overall trend of greater productivity in the east of the catchment where simulated values are mainly between 900 and $1300 \mathrm{~g} \mathrm{C} \mathrm{m}^{-2}$ (Figure 3a). The trait-based model (Figure $3 b$ ) estimates a much wider range of variation in ANPP and maps closely onto the LCM 2007 classification of Figure 2, as would be expected from this vegetationbased surrogate approach. Note that the trait-based model predicts above ground dry mass rather than total carbon above and below ground. LUCI estimates of potential agricultural productivity (Figure 3c), based on soil, and land use data as well as slope and aspect, closely mirror the LCM 2007 classification. Note that this production will not be realised in agricultural terms where the land is forested. Livestock numbers (Figure 3d) approximately reflect the quality of grazing land as indicated by the LCM 2007, again being low in the area dominated by forestry. Comparing the four metrics, it is clear that JULES modelling does not capture the lower NPP in the west of the catchment simulated by the other methods. The JULES estimates are considered to be biased to higher values in failing to 
account for the effects of nutrient limitation arising from altitude, climate, detailed land cover and soil characteristics of this part of the catchment, especially mis-estimating the much lower productivity associated with the high soil $\mathrm{C}$ peat bogs and high altitude acid grasslands. This bias likely results from the coarse global-scale parameterisation used in the JULES model. This limitation is being addressed as part of ongoing development of the JULES model.

To facilitate comparison of the four metrics, probability frequency plots of values of production metrics over the $1 \mathrm{~km}$ grid for the four methods are shown in Figure 4. In all cases, woodland grid squares were excluded as this was not appropriate for the livestock method. The LUCl agricultural potential and plant-trait approach provided broadly similar bi-modal distributions suggesting these two surrogate methods of a vegetation and a land quality based approach do provide similar values. Furthermore, Figure 5 demonstrates the relatively consistent spatial relationship between plant trait based (SLA) ANPP approach and LUCI agricultural potential metrics approaches with each point representing a $1 \mathrm{~km}$ grid square. In Figure 4, the curve for the JULES model is a clear outlier. Even if below-ground production is assumed to represent some $50 \%$ of total ANPP, the overall values would remain greater than for the plant-trait approach which only estimates above-ground production. With regard to the utilisation of production supply i.e. by livestock, Figures 4 and 6 suggest the possibility of a mismatch between animal numbers and carrying capacity of the land with overexploitation in some parts of the catchment although there is continued uncertainty about the quality of the current data captured for livestock numbers. Clearly exploring a bundle of metrics provides a useful approach to exploring the translation of a supporting service to the supply of a provisioning service.

A comparison of the trait-based SLA approach to production estimation in the Conwy catchment with those for Great Britain was undertaken to identify the position of the Conwy catchment within the national context (Maskell et al., 2013; Figure 7). GB results show a bi-modal distribution with optima at around 300 and $800 \mathrm{~kg}$ dry matter/ha/yr. The equivalent frequency plot for the Conwy suggests that the Conwy represents the lower half of the productivity gradient present across GB. This has important implications for the relationships among services (see Section 4).

\subsection{Carbon stock and sequestration potential}

Estimates of current carbon stock are shown in Fig 8. Carbon stock estimates are unsurprisingly particularly high in the area classified as bog (LCM 2007) or peat (NATMAP).

\subsection{Water quality}

The distribution of nitrate and DOC concentrations by sampling site over the period of record is shown in Figure 9. The number of samples taken at each site, and the extent of the sampling period vary between sites, so that the data shown are indicative. The sampling sites shown in Figure 9 show non-independent sites in addition to those used in statistical analysis of the data. At their highest, nitrate-N concentrations do not approach the limit of $11.3 \mathrm{mg} \mathrm{l}^{-1}$ for drinking water (Drinking Water Directive 98/83/EC). They are nevertheless indicative of losses from agricultural land. At higher elevations concentrations may be below the detection limit of $0.01 \mathrm{mg} \mathrm{l}^{-1}$, notably in summer. In winter at some sites there is evidence (not shown) of throughput from nitrogen deposition which cannot be utilised when other factors are limiting (see e.g. McGovern et al. (2014)). As expected, DOC concentrations are notably high in drainage from the Migneint peat area in the south of the 
catchment, and lowest at high elevations where peat is largely absent. Concentrations are also high in the south east part of the catchment where soils are classified as peaty gleys. It is clear from the data that these soils are generating large amounts of DOC, and, based on site visits, it is likely that there is some misclassification of soils in this part of the catchment area. It is likely that carbon stored in this southeastern part of the catchment is higher than indicated in Figure 8, which uses the likely inaccurate soil class. The strong relationship between land cover and water quality confirms earlier work (Langan et al., 1997; Wade et al., 1999).

The distribution of BMWP scores at stream sites sampled is shown in Figure 10. It is not apparent that these scores are related to the nutrient concentrations shown in Figure 9. High and low values appear to be scattered around the catchment. Regression of BMWP scores against a range of water quality variables for Conwy data suggests that it is most closely associated with $\mathrm{pH}$. For our data, BMWP score generally increases with nitrate concentration, but where nitrate concentration is low, there is considerable variation.

Coliform concentrations (both E. coli and non-E. coli) were highly localised at specific sites monitored in the catchment (Figure 10) including the main Conwy river and sites in one tributary in the northeast of the catchment. Concentrations of both non-E. coli coliforms and $E$. coli in the samples collected varied in the range 0 and to $15000 \mathrm{CFU} / 100 \mathrm{ml}$ and exceed the revised Bathing Water Directive (2006/7/EC) classifications of 'excellent quality' (250 E. coli CFU/100 mL) and 'good' or 'sufficient' quality (500 CFU/100 mL) in several areas of the Conwy (see also Quilliam et al. (2011). This localised distribution is believed to be associated with scattered point sources such as septic tanks and sewage treatment works. These results demonstrate the variability in the drivers of change in water quality and their spatial separation within a catchment.

\subsection{Biodiversity}

In descending order, the most species rich habitats (Figure 11a) in the Conwy catchment were estimated to be those classified under LCM 2007 as Neutral Grassland, Broadleaved Woodland and Arable (broad habitat classes in LCM 2007). The most species poor were Bog and Dwarf Shrub Heath (Heather + Heather Grassland). The high species richness for Arable reflects the fact that cultivation in these oceanic and western land classes is often associated with weedier dicotyledonous crops such as Brassica sub-species. Both crop type and climate appear to favour higher alpha diversity (i.e. mean species diversity at the habitat level) in contrast to species-poor intensive grain production in the south and east of Britain (Critchley, 2000).

Locally high biodiversity can often be seen adjacent to the water courses, whereas areas of low habitat diversity are associated with large continuous areas of bogs and moorland at the southern, western and eastern upland areas of the catchment. The more actively managed parts of the valley floor have intermediate levels of habitat diversity.

A significant criticism of this treatment of biodiversity is that it implies that a high biodiversity metric is the valued goal while the type of biodiversity (taxonomic composition, scale of sampling) is not specified; for example Lowland Heath \& Blanket Bog are UK priority habitats and therefore highly valued even though relatively poor in plant species per square metre. Here we equate biodiversity with mean plant species richness per $4 \mathrm{~m}^{2}$ habitat patch averaged across $1 \mathrm{~km}$ squares. While there is fundamental interest in the plant diversity versus productivity relationship, the attachment of value 
to any particular group of species and the density of species co-existing in one place requires a place-specific social negotiation of values alongside considerations such as the wider significance of species in support of various ecosystem functions.

\subsection{Relationship between ecosystem service metrics and productivity}

After generating the grid- or catchment-based estimates of spatial distributions of individual ES metrics, we estimated relationships among them (see Appendix A in Supplementary Material for a summary of the range of values of each of the ES metrics measured or estimated in the Conwy). We carried out multivariate analyses on scaled variables using the RDA routine of the vegan package in the $R$ statistical computing environment (https://cran.rproject.org/web/packages/vegan/vegan.pdf). This procedure follows an equivalent analysis to (Maskell et al., 2013) for the whole of GB and for Wales using survey data from the CS $1 \mathrm{~km}$ square sample. The RDA routine provides both principal components analysis when used without explanatory variables, and redundancy analysis (a multivariate analogue of regression analysis) when explanatory variables are included. Following principal components analysis of the scaled variables we plotted each against the first principal component. From the large number of possible metrics we used the following for principal components analysis: ANPP (plant trait approach), livestock numbers, carbon stock, stream nitrate- $N$ concentration, stream DOC concentration, BMWP score, non-E.coli coliforms, species richness and habitat diversity. We then considered elevation, rainfall, soil $\mathrm{pH}$, soil $\mathrm{C}$, soil $\mathrm{N}$, soil $\mathrm{P}$, soil $\mathrm{C} / \mathrm{N}$ and soil $\mathrm{C} / \mathrm{P}$ ratio as explanatory variables in the RDA analysis, both individually and together.

The analysis was done for ES variables derived from the $1 \times 1 \mathrm{~km}$ gridded dada (Figure 12a) and the subcatchment data (Figure 12b). At both grid and catchment scales ecosystem metrics are a mixture of observed and modelled values. The modelled values have been calculated as simple functions of a common suite of explanatory variables. This common dependence can contribute to correlations between modelled values of metrics.

\section{Discussion}

To determine if there are fundamentally different relationships due to the different forms of discretisation of the land surface, we compared catchment-based and grid-based relationships for all variables (Figures 12a and 12b). In the grid-based approach, each $1 \mathrm{~km}$ grid square is treated as independent in the principal components analysis, when in reality there is spatial correlation among grid squares. This means that unaccounted regional factors may influence the relationships among variables. In the catchment-based approach some of that spatial dependence is removed by aggregating across areas with similar general characteristics. This makes it less likely that unaccounted regional factors will influence the relationship between variables. Despite the differences in approach, both grid- and catchment-based approaches give similar results. The response patterns of the ecosystem service metrics illustrate aspects of the same fundamental trade-off between ecosystem productivity and C storage as seen in Maskell et al. (2013).

While ANPP, livestock density and stream nitrate decline steeply along the environmental gradient, carbon stock and stream DOC increases. The correlations among ANPP, livestock density, carbon 
stock, and nitrate strongly constrain the principal ordination axis and indicate how this axis captures variation in land-use intensity, soil characteristics and nutrient surpluses as production decreases. Species richness appears fairly stable at high to medium productivity, while declining steeply at the low productivity end. Habitat diversity peaks (weakly) near the centre of the gradient, indicating an association with intermediate productivity of soil and vegetation complexes.

The somewhat counterintuitive positive association between mean species richness and productivity measures (Figure 12) reflects the position of the relative position of the Conwy catchment on the overall productivity gradient for GB (Figure 13). Maximum biodiversity is often observed at intermediate / production intensification levels (Adler et al., 2011; Almufti et al., 1977; Fridley et al., 2012; Huston, 2014; Loreau et al., 2001). Thus whilst our findings seem to conflict with this pattern and the findings of Maskell et al. (2013) it is actually entirely consistent. As can be seen from Figure 13 , the limited presence of intensive agricultural practices in the Conwy constrains the ability of our data to discriminate the downturn in biodiversity at the intensive end of the agriculture gradient that is observed at the national scale.

In contrast, whilst the relative position of the Conwy in the national production gradient would suggest limited sensitivity of water quality to the local production gradient (Figure 13), our analysis (Figures $12 \mathrm{a}$ and $\mathrm{b}$ ) indicate a strong reduction in water quality as production increases. This is potentially due to the local and more diverse nature of the data available for the Conwy in comparison to the resolution and scope of the water quality datasets used in the national assessment.

To identify the underlying fundamental environmental constraints which determine the first ordination axis in Figure 12, we analysed the relationships between potential environmental drivers and individual soil metrics (Figure 14a-b). The metrics included are those which show a significant relationship $(p<0.1)$ with potential drivers using the gam routine of the $R$ statistical package with smoothing parameter 0.001 . In addition to rainfall and altitude (the latter to integrate temperature and exposure), we use soil $\mathrm{pH}$ and soil $\mathrm{C} / \mathrm{N}$ values as possible drivers. These soil properties are taken from a GB national-scale topsoil $(0-15 \mathrm{~cm})$ monitoring programme Countryside Survey (Emmett et al. 2010). Values for total carbon, total nitrogen, available-phosphorus (Olsen-P) and $\mathrm{pH}$ within broad habitats were constrained to be in the same land class as those present in the Conwy catchment.

There are no monotonic relationships between service metrics and rainfall or altitude (not shown), while there are generally closer relationships with soil $\mathrm{pH}$ and soil $\mathrm{C} / \mathrm{N}$ ratio, either increasing or decreasing (Figure 14a and $\mathrm{b}$ ). Note that the soil $\mathrm{C} / \mathrm{N}$ ratio is highest when the $\mathrm{C}$ stock is highest. The low soil $\mathrm{pH}$, high soil $\mathrm{C} / \mathrm{N}$ ratio habitat in the Conwy can be considered as one end of the environmental gradient and the productive lower soil $\mathrm{C} / \mathrm{N}$, lower elevation and higher $\mathrm{pH}$ grasslands define the other. The convex trajectory of carbon stock across the rainfall and altitude gradients is a reflection of the fact that the peat coverage is at intermediate altitudes and high, but not the highest, rainfalls. Other metrics are then showing an inverse relationship with carbon stock, because it is to this rather than rainfall and altitude that they are primarily related.

We also used redundancy analysis (RDA) to determine how much of the variation in the service metrics derived from the sub-catchment analysis in the Conwy can be explained by individual measured soil properties in those subcatchments (Table 2). Altitude and rainfall were also included 
in the analyses to provide information about topography and climate. The percentage of variance explained confirm that soil $\mathrm{pH}$ and soil $\mathrm{C}, \mathrm{N}$ and $\mathrm{C} / \mathrm{N}$ ratios are better predictors of ecosystem service metrics considered than rainfall or elevation (as in Figure 14). Maskell et al. (2013) also tested the explanatory power of climate and soil pH of the service metrics but also included Jules NPP and the proportion of land cover but did not include soil nitrogen and phosphorus. Overall, the percentage of overall constrained variance for the Conwy (48\%) was almost twice that explained in the national analysis (27\%). This is likely to be due to the high contrast between landscapes in a relatively small area in the Conwy compared to a national analysis and also potentially due to withinlandscape uniformity within a relatively constrained geographical unit.

Both studies identified soil $\mathrm{pH}$ as amongst the best predictors of ES supply explaining $23 \%$ variation in the national study and $42 \%$ in the Conwy study. Only the proportion of intensive land cover was of comparable magnitude in the national study at $24 \%$ whilst in the Conwy study soil carbon, nitrogen and their ratio had comparable explanatory power (Table 2). This presumably results from the facts that soil $\mathrm{pH}$ reflects underlying geology which is a major factor determining the inherent fertility of soil, plus the fundamental control soil $\mathrm{pH}$ has in determining ecosystem functions such as decomposition, nutrient cycling and soil microbial community structure (e.g. Binkley and Richter (1987)). As soil pH can be determined relatively easily and cheaply in the field with crowd-sourcing options now available for reporting and assessment (Shelley et al., 2013), this may be an alternative simple soil metric for sub-national scale assessments in areas which are less intensively managed such as the Conwy.

\section{Conclusions}

This study confirms a single gradient can be used to characterise the supply of several ecosystem services within the Conwy with agricultural production and carbon storage at opposing ends of the gradient. However the relationship between some ES metrics such as productivity and biodiversity and water quality initially appeared inconsistent with the national assessment until the relative position of the Conwy within the GB productivity gradient was taken into account. These relationships appeared to be robust irrespective of the source of data whether from grid or subcatchment sources. Various soil properties including macronutrient availability had greater predictive power of ecosystem service supply than climate variables. Of these, soil $\mathrm{pH}$ appears to be the simplest and most practical indicator of ecosystem service supply with relevance at both the catchment and national scale. This presumably results from the facts that soil $\mathrm{pH}$ influences a range of ecosystem functions which determine overall ecosystem productivity.

\section{Acknowledgements}

This work was supported by the "Turf2Surf" project under the NERC Macronutrients Cycles Programme Grant No. NE/J011533/1 and NERC / CEH National Capability Project No. NEC04504. We thank all land owners / farmers who have kindly given to access their land and their support and enthusiasm for the work. 


\section{References}

Adler PB, Seabloom EW, Borer ET, Hillebrand H, Hautier Y, Hector A, et al. Productivity Is a Poor Predictor of Plant Species Richness. Science 2011; 333: 1750-1753.

Almufti MM, Sydes CL, Furness SB, Grime JP, Band SR. QUANTITATIVE-ANALYSIS OF SHOOT PHENOLOGY AND DOMINANCE IN HERBACEOUS VEGETATION. Journal of Ecology 1977; 65: 759-791.

Armitage $P$, Moss D, Wright J, Furse M. The performance of a new biological water quality score system based on macroinvertebrates over a wide range of unpolluted running-water sites. Water research 1983; 17: 333-347.

Bennett EM, Peterson GD, Gordon LJ. Understanding relationships among multiple ecosystem services. Ecology Letters 2009; 12: 1394-1404.

Best MJ, Pryor M, Clark DB, Rooney GG, Essery RLH, Menard CB, et al. The Joint UK Land Environment Simulator (JULES), model description - Part 1: Energy and water fluxes. Geoscientific Model Development 2011; 4: 677-699.

Binkley D, Richter D. NUTRIENT CYCLES AND H+ BUDGETS OF FOREST ECOSYSTEMS. Advances in Ecological Research 1987; 16: 1-51.

Bunce RGH, Barr CJ, Clarke RT, Howard DC, Lane AMJ. ITE Merlewood Land Classification of Great Britain. Journal of Biogeography 1996; 23: 625-634.

Burkhard B, Kroll F, Nedkov S, Müller F. Mapping ecosystem service supply, demand and budgets. Ecological Indicators 2012; 21: 17-29.

Cardinale BJ, Matulich KL, Hooper DU, Byrnes JE, Duffy E, Gamfeldt L, et al. The functional role of producer diversity in ecosystems American Journal of Botany 2011; 98: 572-592.

Clark DB, Mercado LM, Sitch S, Jones CD, Gedney N, Best MJ, et al. The Joint UK Land Environment Simulator (JULES), model description - Part 2: Carbon fluxes and vegetation dynamics. Geoscientific Model Development 2011; 4: 701-722.

Cooper DM, Evans CD, Norris D, Thacker S, Pereira MG. Application of a simple multiplicative spatiotemporal stream water quality model to the river Conwy, North Wales. Environmental Science-Processes \& Impacts 2014; 16: 1600-1607.

Costanza R, Fisher B, Mulder K, Liu S, Christopher T. Biodiversity and ecosystem services: A multiscale empirical study of the relationship between species richness and net primary production. Ecological Economics 2007; 61: 478-491.

Critchley CNR. Ecological assessment of plant communities by reference to species traits and habitat preferences. Biodiversity and Conservation 2000; 9: 87-105.

Davy-Bowker J, Furse M, Murphy J, Clarke R, Wiggers R, Vincent H. Development of the AWIC (Acid Water Indicator Community) macroinvertebrate family and species level scoring systems. Monitoring Acid Waters Phase 2003; 1.

Davy-Bowker J, Murphy JF, Rutt GR, Steel JEC, Furse MT. The development and testing of a macroinvertebrate biotic index for detecting the impact of acidity on streams. Archiv Fur Hydrobiologie 2005; 163: 383-403.

Emmett BA, Reynolds B, Chamberlain PM, Rowe E, Spurgeon D, Brittain SA, Frogbrook Z, Hughes S, Lawlor AJ, Poskitt J, Potter E, Robinson DA, Scott A, Wood C, Woods C. Countryside Survey: Soils Report from 2007. NERC/Centre for Ecology \& Hydrology, 2010, 192pp. (CS Technical Report No. 9/07, CEH Project Number: C03259).

Evans CD, Cooper DM, Monteith DT, Helliwell RC, Moldan F, Hall J, et al. Linking monitoring and modelling: can long-term datasets be used more effectively as a basis for large-scale prediction? Biogeochemistry 2010; 101: 211-227.

Fridley JD, Grime JP, Huston MA, Pierce S, Smart SM, Thompson K, et al. Comment on "Productivity Is a Poor Predictor of Plant Species Richness". Science 2012; 335: 1. 
Garnier E, Cortez J, Billes G, Navas ML, Roumet C, Debussche M, et al. Plant functional markers capture ecosystem properties during secondary succession. Ecology 2004; 85: 2630-2637.

Gibbons S, Mourato S, Resende GM. The Amenity Value of English Nature: A Hedonic Price Approach. Environmental \& Resource Economics 2014; 57: 175-196.

Green RE, Cornell SJ, Scharlemann JPW, Balmford A. Farming and the fate of wild nature. Science 2005; 307: 550-555.

Grime JP. Benefits of plant diversity to ecosystems: immediate, filter and founder effects. Journal of Ecology 1998; 86: 902-910.

Huston MA. Disturbance, productivity, and species diversity: empiricism vs. logic in ecological theory. Ecology 2014; 95: 2382-2396.

Huston MA. Local processes and regional patterns: appropriate scales for understanding variation in the diversity of plants and animals. Oikos 1999; 86, 393-401.

Jackson B, Pagella T, Sinclair F, Orellana B, Henshaw A, Reynolds B, et al. Polyscape: A GIS mapping framework providing efficient and spatially explicit landscape-scale valuation of multiple ecosystem services. Landscape and Urban Planning 2013; 112: 74-88.

Langan SJ, Wade AJ, Smart R, Edwards AC, Soulsby C, Billett MF, et al. The prediction and management of water quality in a relatively unpolluted major Scottish catchment: Current issues and experimental approaches. Science of the Total Environment 1997; 194: 419-435.

Laughlin DC. Nitrification is linked to dominant leaf traits rather than functional diversity. Journal of Ecology 2011; 99: 1091-1099.

Littell RC, Stroup WW, Milliken GA, Wolfinger RD, Schabenberger O. SAS for mixed models: SAS institute, 2006.

Loreau M, Naeem S, Inchausti P, Bengtsson J, Grime JP, Hector A, et al. Ecology - Biodiversity and ecosystem functioning: Current knowledge and future challenges. Science 2001; 294: 804808.

Lunn D, Jackson C, Best N, Thomas A, Spiegelhalter D. The BUGS book: A practical introduction to Bayesian analysis: CRC press, 2012.

Malham SK, Rajko-Nenow P, Howlett E, Tuson KE, Perkins TL, Pallett DW, et al. The interaction of human microbial pathogens, particulate material and nutrients in estuarine environments and their impacts on recreational and shellfish waters. Environmental Science-Processes \& Impacts 2014; 16: 2145-2155.

Maskell LC, Crowe A, Dunbar MJ, Emmett B, Henrys P, Keith AM, et al. Exploring the ecological constraints to multiple ecosystem service delivery and biodiversity. Journal of Applied Ecology 2013; 50: 561-571.

McGovern ST, Evans CD, Dennis P, Walmsley CA, Turner A, McDonald MA. Increased inorganic nitrogen leaching from a mountain grassland ecosystem following grazing removal: a hangover of past intensive land-use? Biogeochemistry 2014; 119: 125-138.

Milne R, Brown TA. Carbon in the vegetation and soils of Great Britain. Journal of Environmental Management 1997; 49: 413-433.

Mokany K, Raison RJ, Prokushkin AS. Critical analysis of root: shoot ratios in terrestrial biomes. Global Change Biology 2006; 12: 84-96.

Morris J, Camino M. UK National Ecosystem Assessment. 2011.

Murphy J, Weatherby A. CS Technical Report No. 5/07. Freshwater Manual. NERC/Centre for Ecology and Hydrology. CEH Project, 2008.

Murray-Bligh J. Procedures for collecting and analysing macro-invertebrate samples: Environment Agency, 1999.

Norton LR, Maskell LC, Smart SS, Dunbar MJ, Emmett BA, Carey PD, et al. Measuring stock and change in the GB countryside for policy - Key findings and developments from the Countryside Survey 2007 field survey. Journal of Environmental Management 2012; 113: 117-127.

Ntzoufras I. Bayesian modeling using WinBUGS. Vol 698: John Wiley \& Sons, 2011. 
Quilliam RS, Clements K, Duce C, Cottrill SB, Malham SK, Jones DL. Spatial variation of waterborne Escherichia coli - implications for routine water quality monitoring. Journal of Water and Health 2011; 9: 734-737.

Raudsepp-Hearne C, Peterson GD, Bennett EM. Ecosystem service bundles for analyzing tradeoffs in diverse landscapes. Proceedings of the National Academy of Sciences of the United States of America 2010; 107: 5242-5247.

Reich PB. The world-wide 'fast-slow' plant economics spectrum: a traits manifesto. Journal of Ecology 2014; 102: 275-301.

Reid W. Millennium Ecosystem Assessment synthesis report. http://www.milleniumassessment.org/en/Products. Synthesis. aspx, 219p, 2005.

Robinson EL, Blyth E, Clark DB, Finch J, Rudd AC. Climate hydrology and ecology research support system meteorology dataset for Great Britain (1961-2012) [CHESS-met]. NERC Environmental Information Data Centre 10.5285/80887755-1426-4dab-a4a6-250919d5020c 2015.

Shelley W, Lawley R, Robinson DA. Crowd-sourced soil data for Europe. Nature 2013; 496:300.

Smart SM, Bunce RGH, Firbank LG, Coward P. Do field boundaries act as refugia for grassland plant species diversity in intensively managed agricultural landscapes in Britain? Agriculture Ecosystems \& Environment 2002; 91: 73-87.

Swetnam RD, Fisher B, Mbilinyi BP, Munishi PKT, Willcock S, Ricketts T, Mwakalila S, Balmford A, Burgess ND, Marshall AR, Lewis SL. Mapping socio-economic scenarios of land cover change: a GIS method to enable ecosystem service modelling. Journal of Environmental Management, 2010. doi:10.1016/j.jenvman.2010.09.007.

Thorn CE, Quilliam RS, Williams AP, Malham SK, Cooper D, Reynolds B, et al. Grazing intensity is a poor indicator of waterborne Escherichia coli 0157 activity. Anaerobe 2011; 17: 330-333.

Turner RK, Daily GC. The ecosystem services framework and natural capital conservation. Environmental and Resource Economics 2008; 39: 25-35.

Vile D, Shipley B, Garnier E. Ecosystem productivity can be predicted from potential relative growth rate and species abundance. Ecology Letters 2006; 9: 1061-1067.

Wade AJ, Neal C, Soulsby C, Smart RP, Langan SJ, Cresser MS. Modelling streamwater quality under varying hydrological conditions at different spatial scales. Journal of Hydrology 1999; 217: 266-283.

Whitehead PG, Crossman J. Macronutrient cycles and climate change: Key science areas and an international perspective. Science of the Total Environment 2012; 434: 13-17.

Wright IJ, Reich PB, Westoby M, Ackerly DD, Baruch Z, Bongers F, et al. The worldwide leaf economics spectrum. Nature 2004; 428: 821-827. 


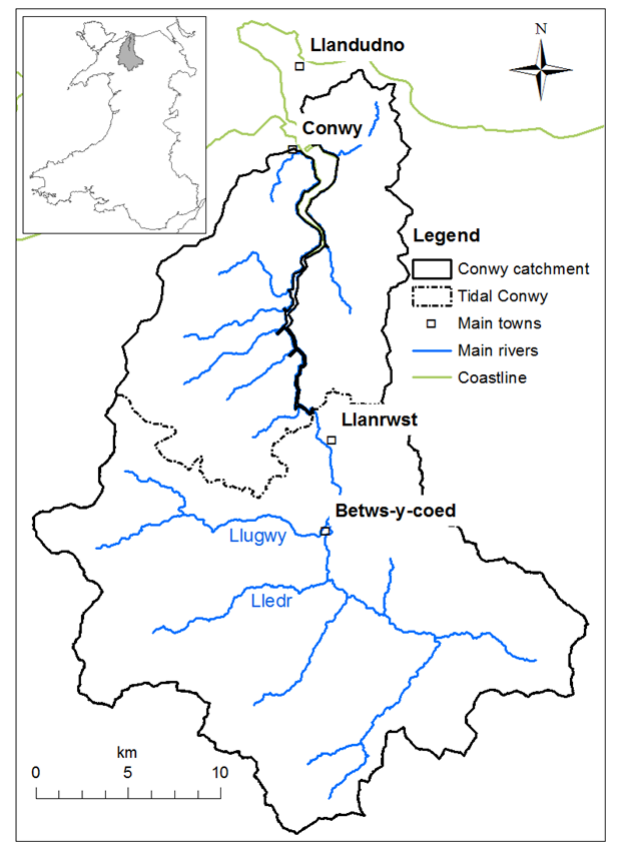

Figure 1. The Conwy river and catchment in North Wales, UK $\left(3^{\circ} 50^{\prime} \mathrm{W}, 53^{\circ} 00^{\prime} \mathrm{N}\right)$. 
a)

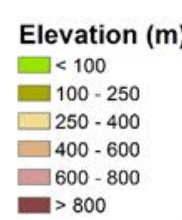

c)

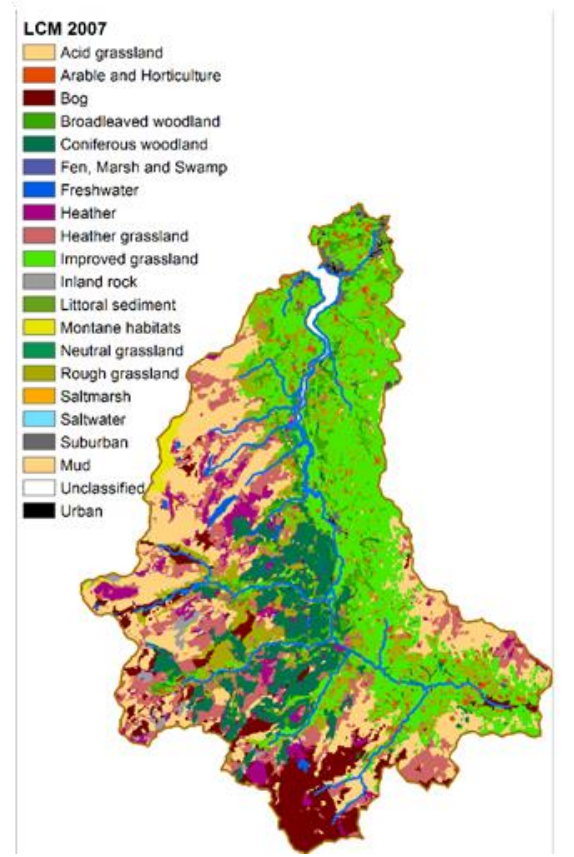

b)

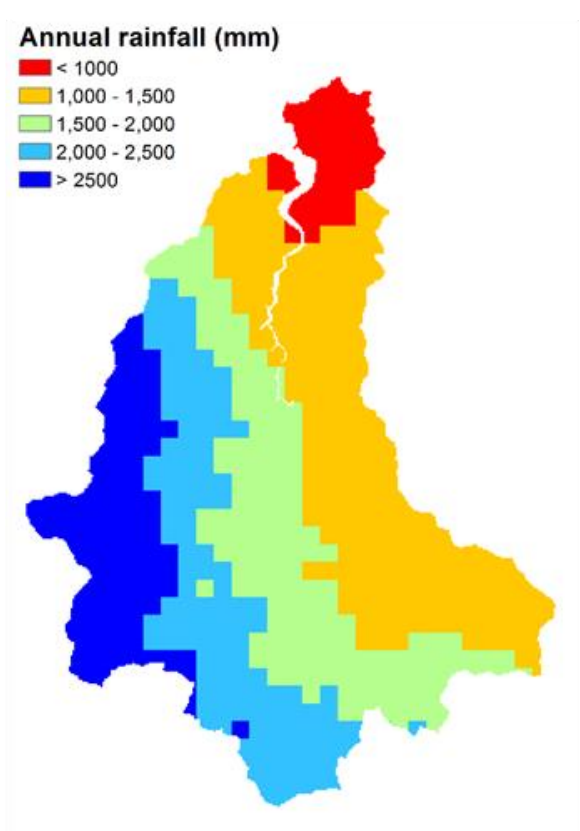

d)

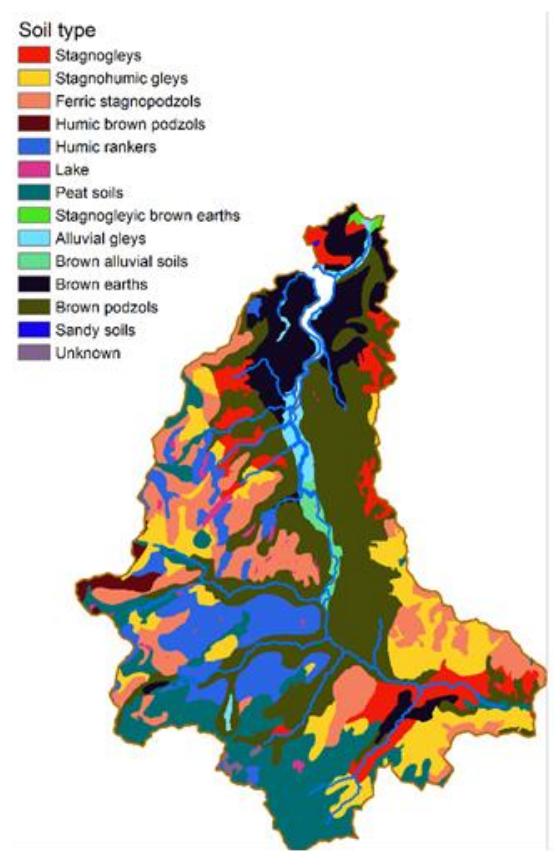

Figure 2. The Conwy catchment: a) elevation; b) annual rainfall; c) land cover (LCM 2007); and d) soil type. 


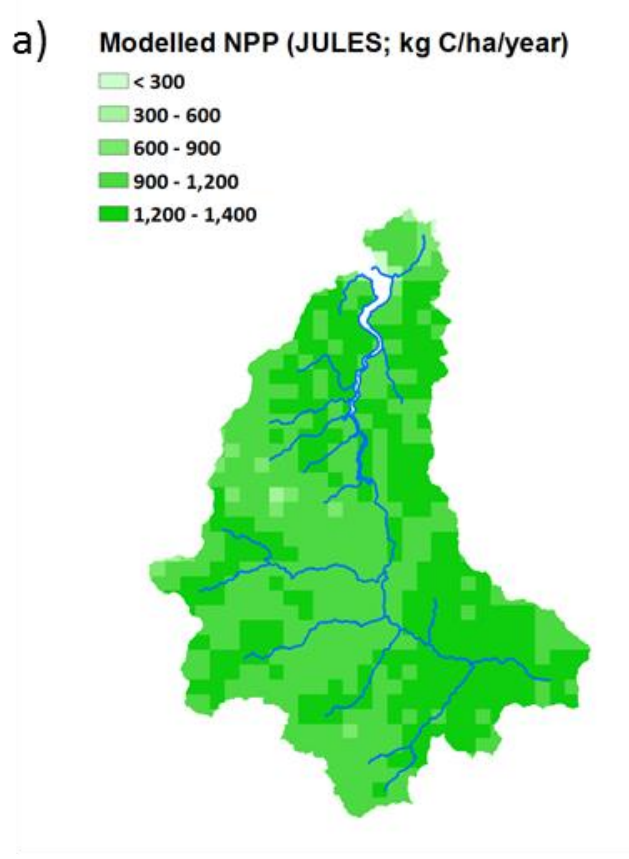

c)

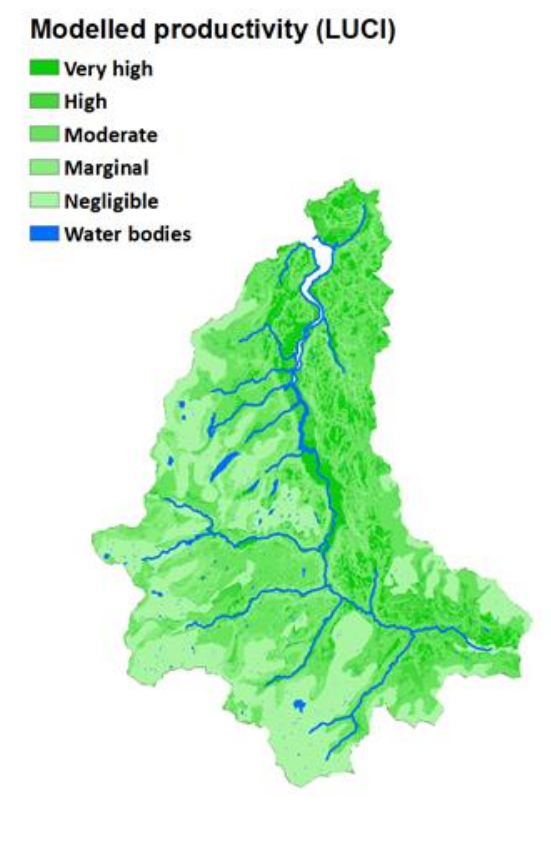

b) Modelled ANPP (SLA; $\mathbf{k g}$ C/ha/year)

$$
\begin{aligned}
& \square<300 \\
& \square 300-325 \\
& \square 325-350 \\
& =350-400 \\
& >400
\end{aligned}
$$

d) Livestock ( $\mathrm{No} / \mathrm{sq} \mathrm{km)}$

$\square<100$

$$
\square 101-200
$$$$
201-300
$$$$
\text { - } 301-400
$$

$\square \mathbf{4 0 0}$

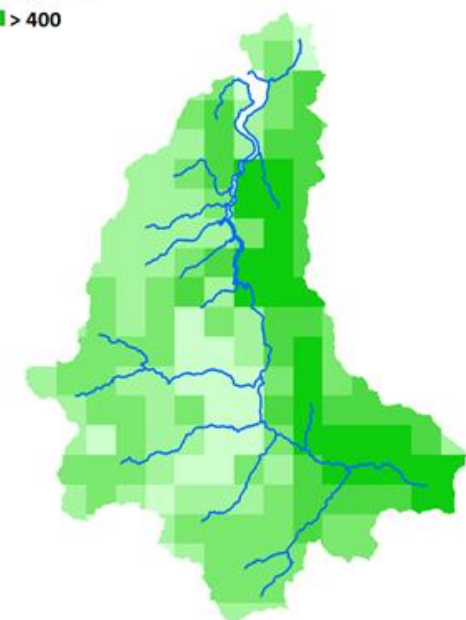

Figure 3. Estimates of NPP for the Conwy catchment from: a) JULES model; b) Plant-trait based model; c) agricultural potential index; and d) livestock density. 


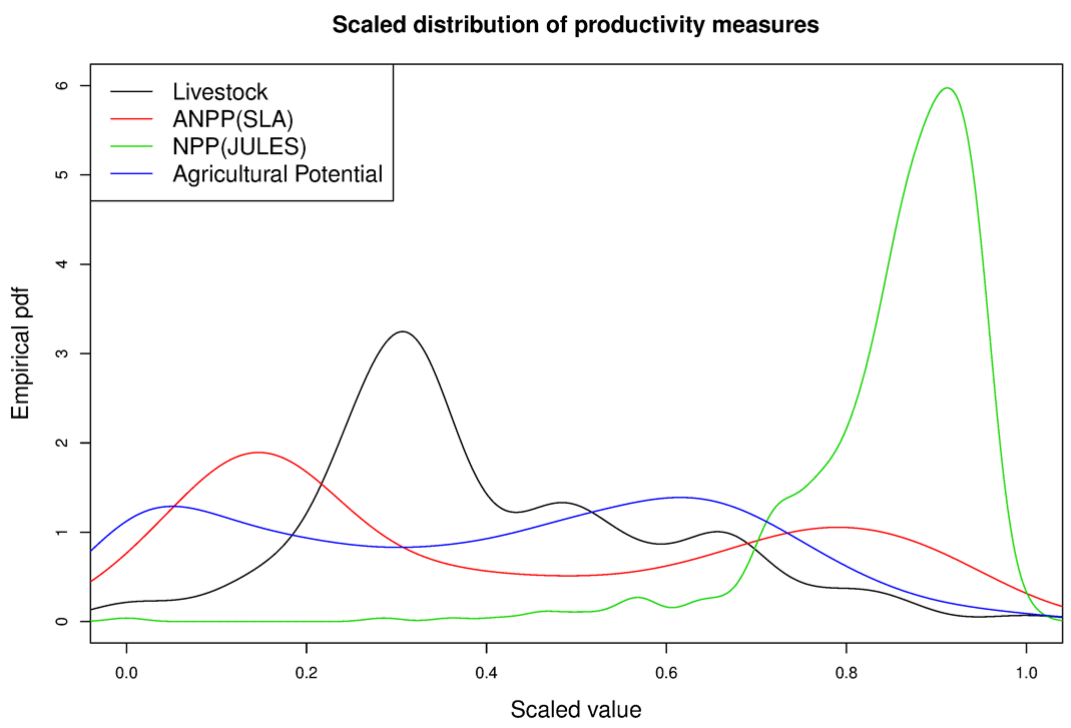

Figure 4. Smoothed probability distribution function (pdf) for the four approaches to estimating spatial patterns of productivity across the Conwy catchment excluding woodland grid squares. Low values on the $x$-axis indicate low productivity estimates. Each metric is scaled between 0 and 1. 


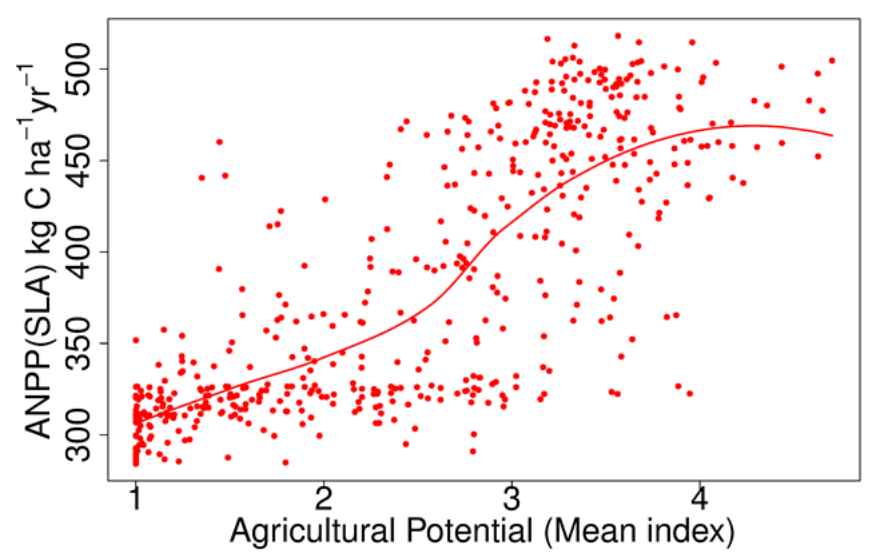

Figure 5. Productivity estimates showing ANPP from the plant trait approach (SLA) against LUCI agricultural potential.

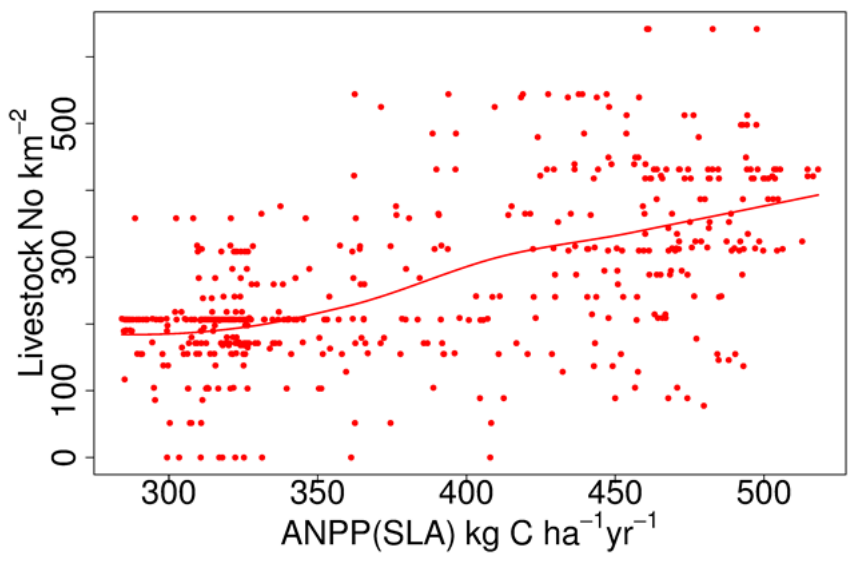

Figure 6. Productivity estimates showing livestock numbers against plant trait based approach (SLA). 


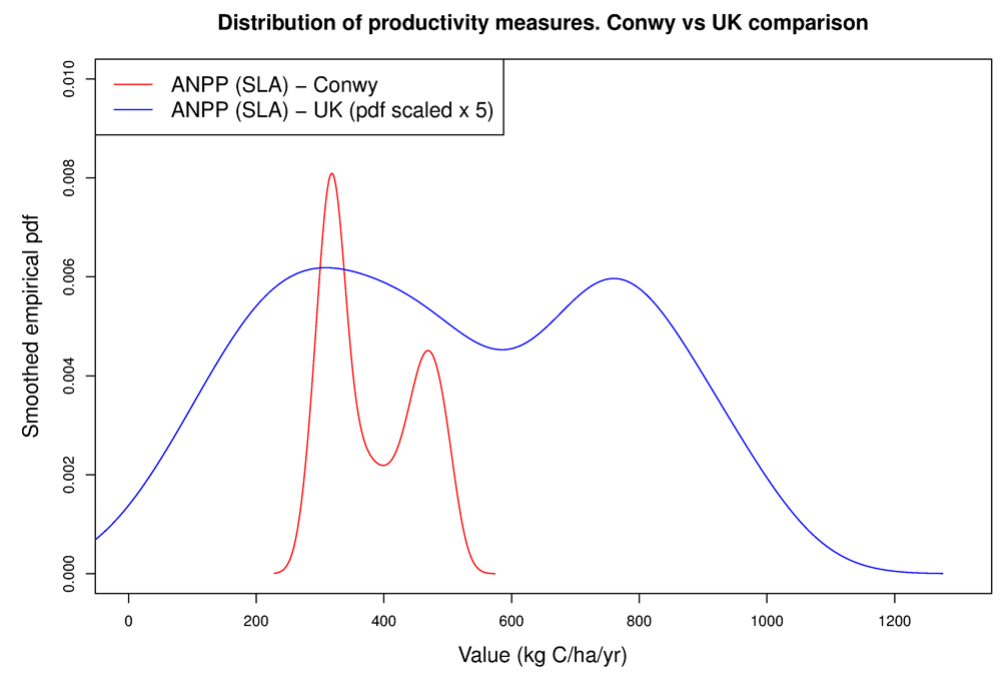

Figure 7. Probability distribution function (pdf) of annual above-ground net primary production for Great Britain and the Conwy using the plant trait-based approach. 


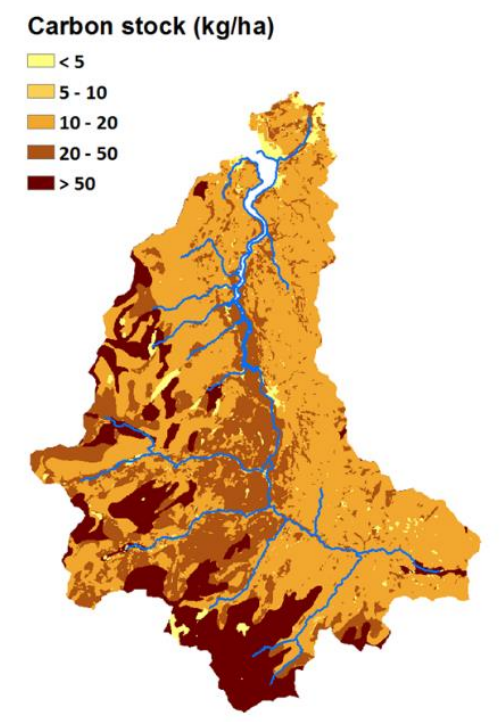

Figure 8. Climate mitigation metrics in the Conwy catchment: carbon stock in soils 

a) Nitrate N (mg/l)
- $0.25-0.75$
$0.75-1.25$
- $1.25-2.50$
- $>2.5$

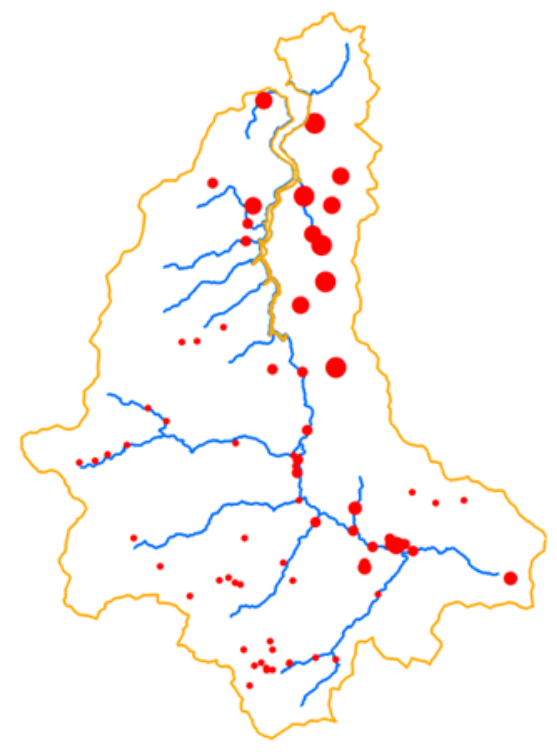

b) Dissolved organic carbon ( $\mathrm{mg} / \mathrm{l} \mathrm{C}$ )

$$
\text { - }<2.0
$$

- $2.0-4.0$

- $4.0-6.0$

- $6.0-8.0$

$8.0-12.0$

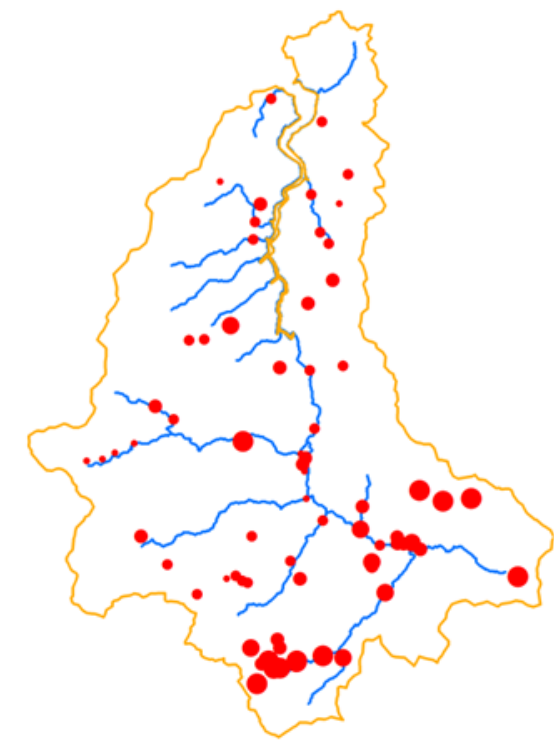

Figure 9. Streamwater quality metrics in the Conwy catchment: a) Nitrate- $\mathrm{N} \mathrm{mg/l}$; and b) dissolved organic carbon (DOC) $\mathrm{mg} / \mathrm{l}$. 
a) BMWP score

$\cdot<70$

- $70-90$

- $90-110$

- $110-140$

- $140-165$

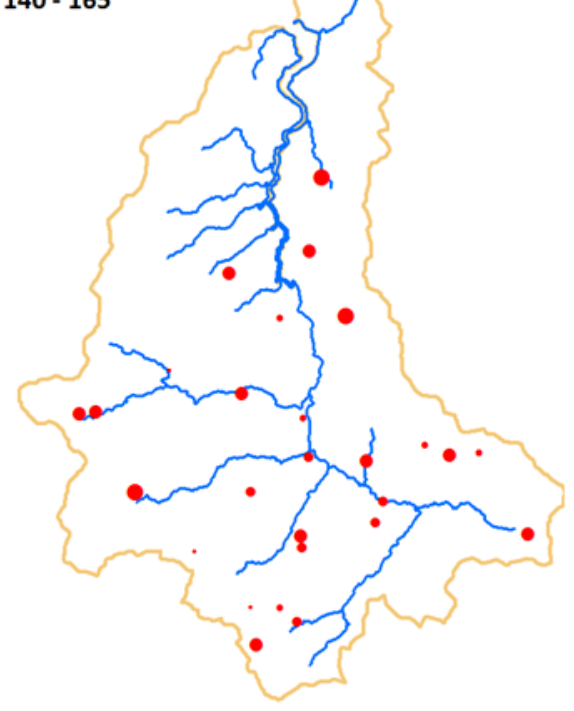

b) Coliforms (cfu/100 ml)

$\cdot<600$

- $600-1200$

- $1200-2000$

- $2000-3000$

- $>3000$

Figure 10. Ecological status metrics in the streams of the Conwy catchment: a) BMWP scores; and b) Non-E. coli coliform counts. 
a) Species richness (vascular plants/4 sq $\mathrm{m}$ )

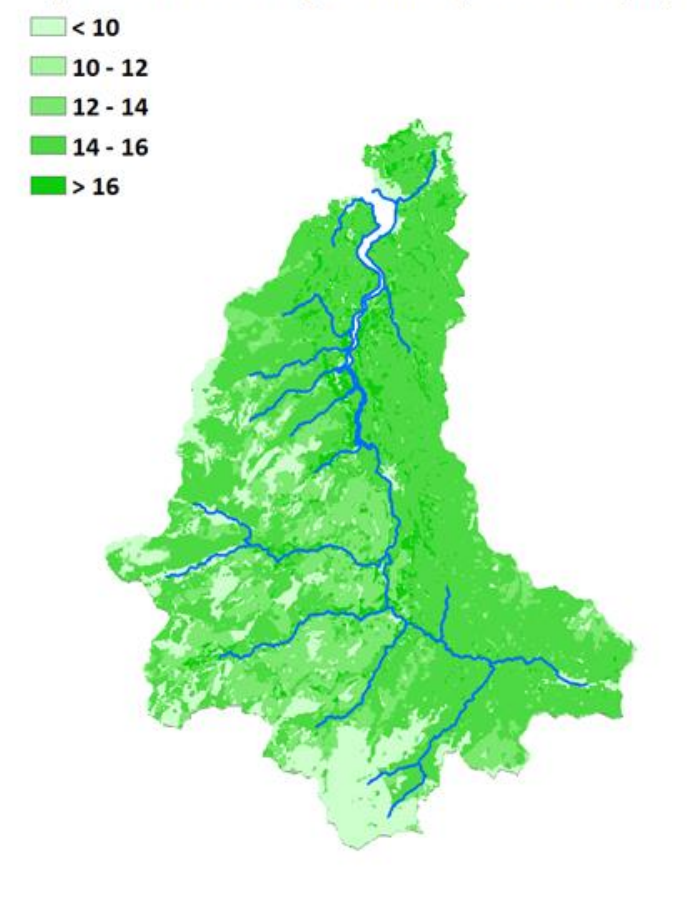

b) Habitat diversity

$1-3$

$4-5$

$6-7$

$8-9$

=10-12

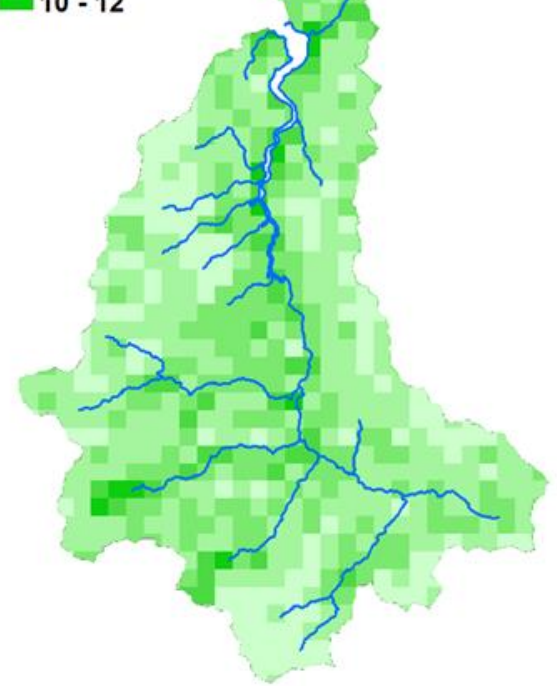

Figure 11. Biodiversity metrics for the Conwy catchment: a) Estimated vascular plant species richness; and b) habitat diversity. 
a)

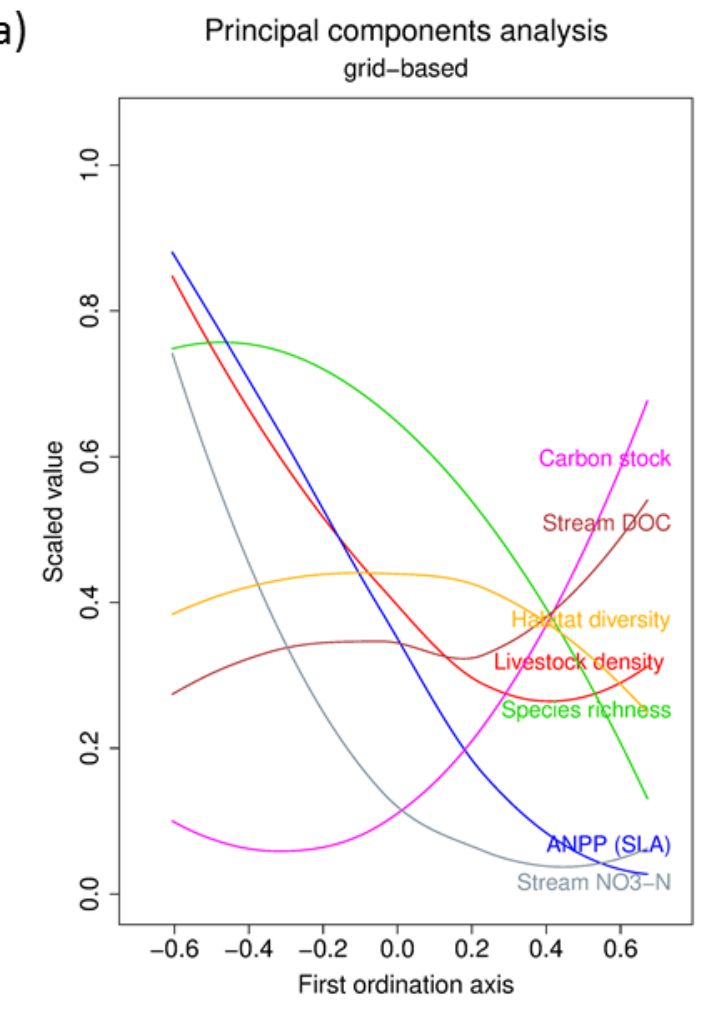

b) Principal components analysis catchment-based

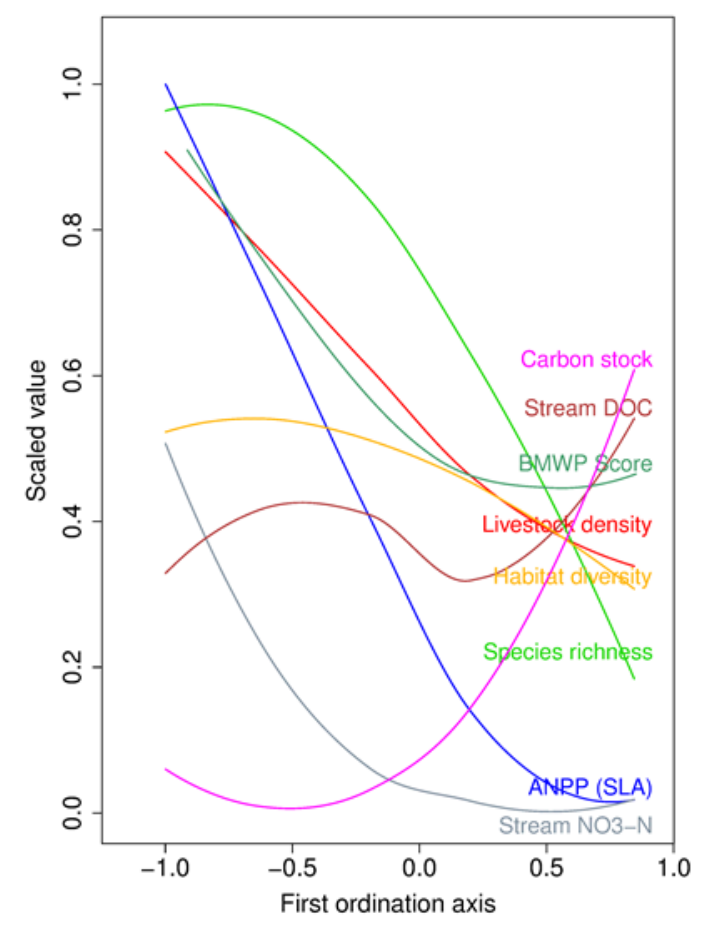

Figure 12. A comparison of the relationships among ecosystem service metrics in the Conwy catchment at the: a) $1 \times 1 \mathrm{~km}$ grid scale; and b) sub-catchment scale. 


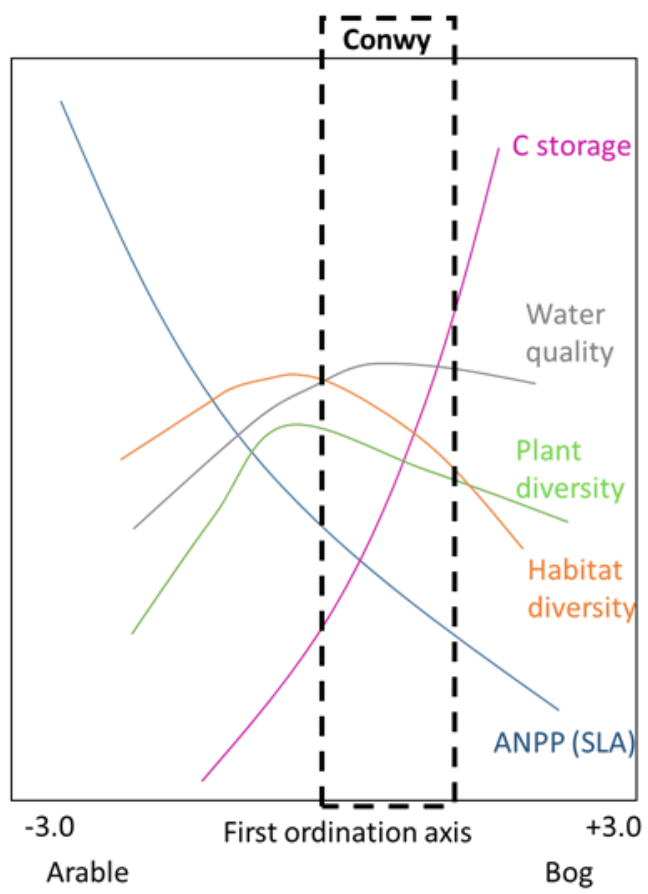

Figure 13. The relationship among ecosystem service metrics at the national scale according to Maskell et al (2013). The position of the Conwy within the national productivity gradient is indicated by the dashed box. The covariance amongst other ecosystem services within this box are those which would be predicted for the Conwy catchment from this national scale assessment. 

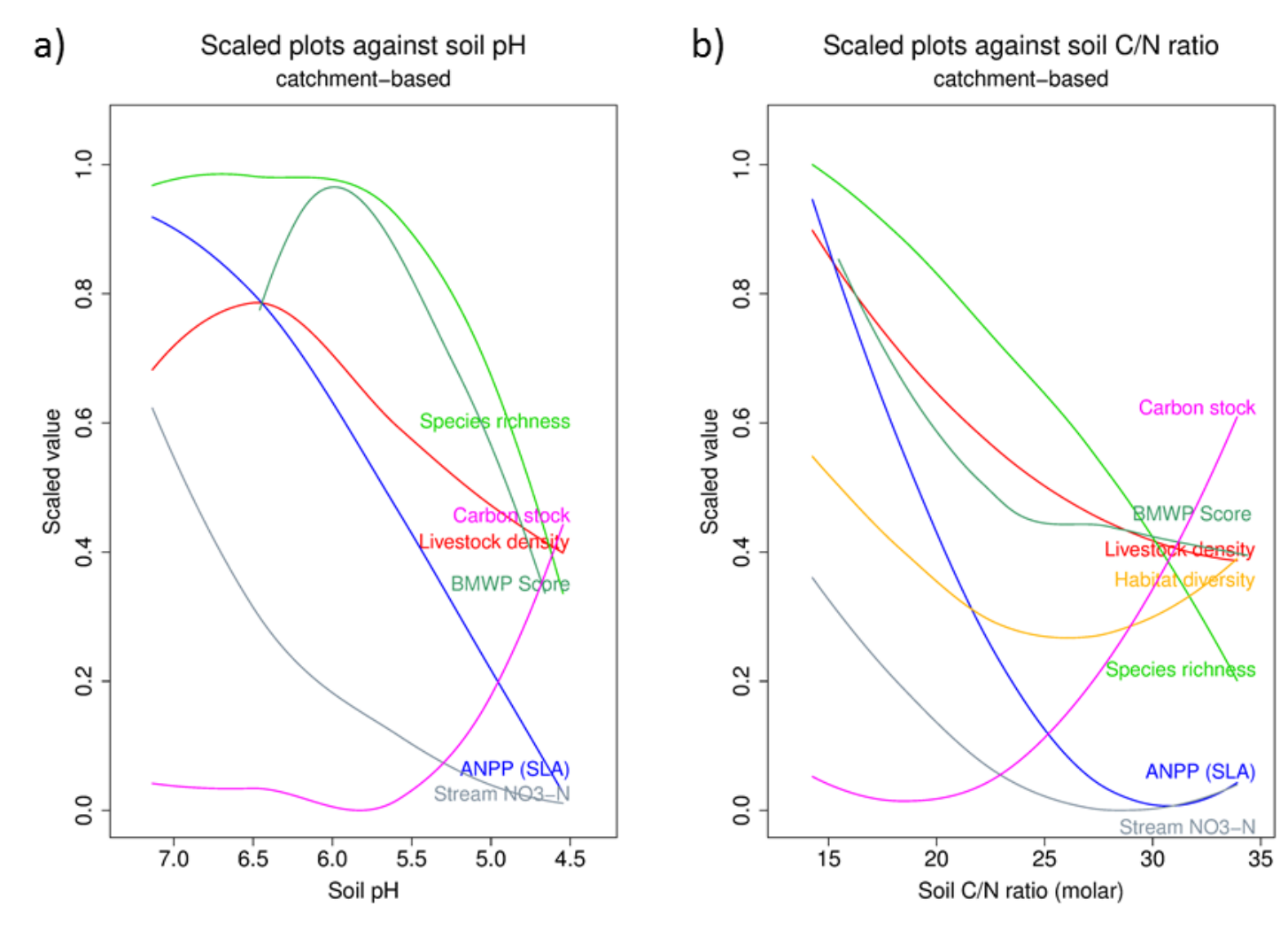

Figure 14. Ecosystem service indicator variables in the Conwy catchment as a function of: a) soil $\mathrm{pH}$; and b) soil $\mathrm{C} / \mathrm{N}$ ratio. 
Table 1. Distribution of ecosystem service variable values in the Conwy. Water quality data are for headwater subcatchments. All others are metrics are for the $1 \times 1 \mathrm{~km}$ grids. Means were calculated for the gridded data, medians were calculated for the subcatchment data.

\begin{tabular}{|c|c|c|c|c|c|}
\hline \multicolumn{2}{|r|}{ Service } & Units & Min & Mean/ & Max \\
\hline \multirow{4}{*}{$\begin{array}{l}\text { Production } \\
\text { (mean) }\end{array}$} & $\begin{array}{l}\text { JULES model: Total Net Primary } \\
\text { Production (NPP) }\end{array}$ & $\mathrm{kg} \mathrm{C} / \mathrm{ha} / \mathrm{yr}$ & 40 & 1150 & 1300 \\
\hline & $\begin{array}{l}\text { Plant-trait based (SLA): Above- } \\
\text { ground Net Primary Production } \\
\text { (ANPP) }\end{array}$ & $\mathrm{kg} \mathrm{C} / \mathrm{ha} / \mathrm{yr}$ & 280 & 380 & 520 \\
\hline & LUCI model: Agriculture potential & Classification & 1 & 3 & 5 \\
\hline & Livestock numbers & $\mathrm{No} / \mathrm{km}^{2}$ & 0 & 100 & 650 \\
\hline $\begin{array}{l}\text { Carbon } \\
\text { (mean) }\end{array}$ & Carbon stock & $\mathrm{kg} / \mathrm{ha}$ & 0 & 23 & 120 \\
\hline \multirow{4}{*}{$\begin{array}{l}\text { Water } \\
\text { quality } \\
\text { (median) }\end{array}$} & Nitrate-N & $\mathrm{mg} / \mathrm{l}$ & $<0.01$ & 0.15 & 4.2 \\
\hline & DOC & $\mathrm{mg} / \mathrm{l}$ & 0.1 & 4.3 & 25 \\
\hline & BMWP & Index & 40 & 110 & 160 \\
\hline & Coliforms & $\mathrm{cfu} / 100 \mathrm{ml}$ & 0 & 1272 & $>3000$ \\
\hline \multirow{2}{*}{$\begin{array}{l}\text { Biodiversity } \\
\text { (mean) }\end{array}$} & $\begin{array}{l}\text { Species richness; Mean plant } \\
\text { species richness in a } 4 \mathrm{~m} 2 \text { survey } \\
\text { plot weighted by the extent of } \\
\text { each habitat in each } 1 \mathrm{~km}^{2} \text { square }\end{array}$ & $\begin{array}{l}\text { Number } \\
\text { vascular } \\
\text { plants } / 4 \mathrm{~m}^{2} \\
/ \mathrm{km}^{-2}\end{array}$ & 9 & 14 & 18 \\
\hline & $\begin{array}{l}\text { Habitat diversity; Number of } \\
\text { dominant land cover classes in } \\
\text { each } 1 \mathrm{~km}^{2}\end{array}$ & $\begin{array}{l}\text { Number of } \\
\text { landcover } \\
\text { classes } / \mathrm{km}^{2}\end{array}$ & 1 & 5 & 12 \\
\hline
\end{tabular}


Table 2. Redundancy analysis (RDA) results to determine the percentage of variance explained by selected soil variables, altitude and rainfall. All variables are subcatchment based.

\begin{tabular}{|c|c|c|c|}
\hline Variable & $\begin{array}{c}\text { Percentage } \\
\text { variance } \\
\text { explained }\end{array}$ & F & P \\
\hline Unconstrained & 49 & 40.8 & $<0.005$ \\
\hline Soil C & 45 & 38.8 & $<0.005$ \\
\hline Soil C/N & 44 & 36.4 & $<0.005$ \\
\hline Soil N & 43 & 35.2 & $<0.005$ \\
\hline Soil pH & 42 & 25.4 & $<0.005$ \\
\hline Soil C/P & 34 & 16.7 & $<0.005$ \\
\hline Rainfall (SAAR) & 25 & 15.2 & $<0.005$ \\
\hline Altitude & 24 & 4.50 & 0.005 \\
\hline Soil P & 8 & 15.5 & $<0.005$ \\
\hline All constrained & 48 & & \\
\hline
\end{tabular}




\section{Appendix A - Description of the Conwy Research Catchment.}

The river Conwy is the third largest river discharging into the Irish Sea along the north Wales coast. It drains a catchment of $678 \mathrm{~km} 2$, the main drainage channel covering a distance of $55 \mathrm{~km}$. The upper reaches of the river drain the Migneint - one of the largest blanket bogs in Wales and a major store of carbon. Further downstream the Conwy is joined by tributaries (Machno, Lledr and Llugwy) draining the eastern side of the Snowdonia mountain range, before reaching the tidal limit, $20 \mathrm{~km}$ inland from the estuary mouth. For much of its length the tidal Conwy flows through a vulnerable floodplain, and is generally no more than $200 \mathrm{~m}$ in width, receiving inflows from a number of minor tributaries.

There is a strong climatic gradient across the catchment with annual rainfall varying between $500 \mathrm{~mm}$ in the north-east to more than $3500 \mathrm{~mm}$ falling in the Snowdonia mountains to the west. The underlying geology is a mix of Silurian mudstones to the east and harder mixed igneous and sedimentary Cambrian formations to the west. The proportions of major soils are close to the Welsh national average, and typical of UK upland areas.

Land use varies from mountain and moorland with extensive sheep grazing and areas of coniferous forestry plantation in the headwaters and on poorer ground, to intensive sheep, beef and dairy farming with some arable production in lower elevation and more productive land. Semi-natural woodland can be found in many of the Conwy's tributary catchments, including important areas of wet woodland. There are drinking water supply reservoirs (Llyn Conwy and Llyn Cowlyd) along with hydropower generation (e.g. at Dolgarrog). Recreation and tourism are important to the local economy and the catchment is a significant fishery for sea trout and salmon. The Conwy estuary also contains commercial shellfish beds. Tables A1 to A4 contain further details of the Conwy Catchment.

\begin{tabular}{|c|c|c|}
\hline \multicolumn{3}{|c|}{ Conwy Catchment } \\
\hline \multirow[t]{2}{*}{ Area $\left(\mathrm{km}^{2}\right)$} & Total & 580 \\
\hline & Above tidal limit & 380 \\
\hline \multirow[t]{3}{*}{ Elevation (m) } & Minimum & 0 \\
\hline & River headwaters & 460 \\
\hline & Maximum & 1064 \\
\hline \multirow[t]{2}{*}{ Geology } & Age & Mixed Paleozoic \\
\hline & Type & Igneous, Sedimentary \\
\hline \multirow[t]{2}{*}{ Landscape } & Dominant soils & $\begin{array}{c}\text { Brown podzols, } \\
\text { peats, gleys }\end{array}$ \\
\hline & Dominant land use & $\begin{array}{l}\text { Upland Farming, Arable, } \\
\text { Mixed Livestock, Woodland }\end{array}$ \\
\hline Rainfall (mm) & Mean annual, sea level & 500 \\
\hline
\end{tabular}




\begin{tabular}{|c|c|c|}
\hline & Mean annual, high elevation & 3500 \\
\hline \multirow{3}{*}{$\begin{array}{l}\text { Air temperature (deg C) } \\
\text { ( } 216 \mathrm{~m} \mathrm{ASL)}\end{array}$} & Mean annual & 10 \\
\hline & February & 5 \\
\hline & July & 15 \\
\hline \multirow[t]{2}{*}{ Population (number) } & Urban/suburban & 10,000 \\
\hline & Rural & 10,800 \\
\hline \multirow{5}{*}{$\begin{array}{l}\text { Economic activity } \\
\text { (\% working population) }\end{array}$} & Wholesale and retail & 16 \\
\hline & Health-related & 14 \\
\hline & Education & 12 \\
\hline & Tourism & 10 \\
\hline & Agriculture, forestry, fishing & 4 \\
\hline \multicolumn{3}{|l|}{ Conwy River } \\
\hline \multirow[t]{2}{*}{ River channel length (km) } & Main channel & 55 \\
\hline & Above tidal Limit & 35 \\
\hline \multirow{4}{*}{$\begin{array}{l}\text { River discharge }\left(\mathrm{m}^{3} \mathrm{~s}^{-1}\right) \\
\text { (at tidal limit) }\end{array}$} & Mean annual & 18.7 \\
\hline & Q95 & 1.35 \\
\hline & Q10 & 45.3 \\
\hline & Median annual flood max & 376 \\
\hline \multirow{5}{*}{$\begin{array}{l}\text { Chemical water quality, } \\
\text { concentration ranges } \\
\left(\mathrm{mg} \mathrm{l}^{-1}\right) \quad \text { (at tidal limit) }\end{array}$} & Nitrate-N & $0.2-2.8$ \\
\hline & Ammonium-N & $<0.03-0.04$ \\
\hline & Phosphate-P & $<0.02-0.05$ \\
\hline & Dissolved organic C & $1.5-10$ \\
\hline & $\mathrm{pH}$ & $5.7-7.2$ \\
\hline \multirow{2}{*}{$\begin{array}{l}\text { Biological water quality, } \\
\text { indicator ranges } \\
\text { (scores) (in headwaters) }\end{array}$} & $\begin{array}{l}\text { Biological Monitoring Working } \\
\text { Party (BMWP) }\end{array}$ & $40-160$ \\
\hline & $\begin{array}{l}\text { Acid Water Indicator } \\
\text { Community (AWIC) }\end{array}$ & $20-110$ \\
\hline
\end{tabular}

\begin{tabular}{|l|l|l|l|}
\hline \multirow{2}{*}{$\begin{array}{c}\text { Table A-2. Percent of land cover in different } \\
\text { WCM } \begin{array}{c}\text { E07les, and England \& Wales } \\
\text { Wass in the Conwy catchment, }\end{array}\end{array}$} & \multicolumn{3}{|c|}{ Percent land cover } \\
\cline { 2 - 4 } & Conwy & Wales & $\begin{array}{l}\text { England } \\
\text { \& Wales }\end{array}$ \\
\hline Broadleaved woodland & 5.07 & 5.96 & 6.96 \\
\hline Coniferous woodland & 9.89 & 6.92 & 2.96 \\
\hline Arable and horticulture & 1.58 & 8.40 & 36.38 \\
\hline Improved grassland & 24.67 & 40.43 & 29.10 \\
\hline Rough grassland & 10.91 & 10.40 & 4.69 \\
\hline Neutral grassland & 0.36 & 0.36 & 0.79 \\
\hline Acid grassland & 20.56 & 13.80 & 3.99 \\
\hline Fen, marsh and swamp & 0.01 & 0.03 & 0.05 \\
\hline Heather & 4.09 & 2.10 & 1.24 \\
\hline Heather grassland & 11.27 & 3.29 & 1.89 \\
\hline Bog & 7.46 & 2.01 & 1.58 \\
\hline
\end{tabular}




\begin{tabular}{|l|l|l|l|}
\hline \multirow{2}{*}{$\begin{array}{c}\text { Table A-3. Percent of land area in different } \\
\text { soil classifications in the Conwy catchment, } \\
\text { Wales, and England plus Wales }\end{array}$} & \multicolumn{3}{|c|}{ Percent land area } \\
\cline { 2 - 4 } & Conwy & Wales & $\begin{array}{l}\text { England } \\
\text { \& Wales }\end{array}$ \\
\hline Humic rankers & 9.87 & 1.56 & 0.72 \\
\hline Typical sand-pararendzinas & 0.02 & 0.54 & 0.27 \\
\hline Typical brown earths & 9.35 & 26.18 & 13.53 \\
\hline Typical brown alluvial soils & 1.02 & 1.83 & 0.75 \\
\hline Stagnogleyic argillic brown earths & 0.17 & 0.63 & 5.74 \\
\hline Typical brown podzolic soils & 29.00 & 22.15 & 4.85 \\
\hline Humic brown podzolic soils & 1.00 & 1.29 & 0.35 \\
\hline Ferric stagnopodzols & 14.02 & 8.78 & 1.40 \\
\hline Cambic stagnogley soils & 7.33 & 15.07 & 6.08 \\
\hline Cambic stagnohumic gley soils & 12.12 & 8.04 & 3.59 \\
\hline Typical alluvial gley soils & 1.72 & 1.92 & 0.97 \\
\hline Raw oligo-amorphous peat soils & 14.15 & 3.30 & 0.54 \\
\hline
\end{tabular}




\section{Appendix B - Derivation of an empirical model of annual above-ground Net Primary Production}

\section{Methods}

NPP and plant species compositional data

During summer 2008, plant species composition was recorded in varying numbers of random $1 \mathrm{~m}^{2}$ quadrats on each of seven experimental sites (Figure B1 and Table B1). NPP was also measured for these quadrat locations by cutting, drying and weighing aboveground biomass in $50 \mathrm{~cm}^{2}$ sub-plots. In grazed systems, exclosures (gabion cages) were established over the biomass plots in late winter and grazers excluded until harvesting at the end of the growing season. While this method does not overcome possible issues with negative and positive compensatory growth as a result of grazing, uncertainty over the importance and direction of these effects is great and no clearly superior method appears to exist that accounts for these effects while also excluding grazers (McNaughton, Milchunas \& Frank 1996). In the upland broadleaved woodland site NPP was measured as the sum of the herbaceous understorey production, estimated from grazing exclosures as above, coupled with annual tree leaf production.

To ensure coverage of the terrestrial ecosystem productivity gradient we extracted additional data for six ecosystems from published sources. NPP values and paired plant species cover data for montane calcareous grassland were taken from (Perkins et al. 1978) and for ombrogenous blanket mire from Tables 2 and 13 in (Forrest \& Smith 1975). In all cases NPP and plant species composition were measured in the same locations at the same time. Two methods were used to measure NPP in the upland calcareous grassland; (1) hand clipping of vegetation above the plant bases; (2) separation of all living above-ground material from turf cores $(6 \mathrm{~cm}$ in diameter and $8.5 \mathrm{~cm}$ in depth) collected to determine root and above-ground production. We averaged the values of above-ground biomass from both methods. Independent test data for measured NPP under natural conditions for two key herbaceous dominants characterising wet heath in north west Europe (Erica tetralix L. and Molinia caerulea (L.) (Moench) were extracted from (Aerts \& Berendse 1989). Paired NPP and species compositional data were also extracted from (Smart et al. 2002) for two unimproved, species rich hay meadows and two intensively managed lowland grasslands (Table B1).

\section{Abundance-weighted Specific Leaf Area}

We extracted species-specific SLA values from (Grime et al. 1995) with additional values from (Kleyer et al. 2008) and (Wright et al. 2004). All vascular plant species had SLA values. Having attached these to the plant species abundance data, mean abundance-weighted SLA for each sample plot was calculated as,

$$
m S L A_{j}=\operatorname{sum}\left(S L A_{i j} \times\left(\operatorname{cov}_{i j}\right)\right) / \operatorname{sum}\left(\operatorname{cov}_{i j}\right) \text {, }
$$

where $\left(\operatorname{cov}_{i j}\right)$ was the percentage cover value for species $i$ in each sample plot $j$. SLA values are not widely available for bryophytes and so they did not contribute to calculations. All calculations of mSLA used a single published value per species. 
Species richness was calculated as the count of all vascular plant species in each plot. Species diversity was based on the Shannon-Wiener index (SW) where richness is weighted by the proportional contribution of each species to total abundance in each plot as follows;

$$
S W=-1 * \Sigma\left(p_{i}^{*} \ln \left(p_{i}\right)\right)
$$

where $\mathrm{p}_{\mathrm{i}}=$ the proportion of the total cover of higher plants in each plot contributed by species $\mathrm{i}$.

\section{$\underline{\text { Statistical analysis }}$}

Because measurements of above-ground NPP and mSLA were clustered by ecosystem type, a hierarchical modelling approach was adopted to ensure that the non-independence of plots within sites was fully accounted for and that variances were correctly modelled given the nested structure of the data. We applied a Bayesian random effects model with fixed effects of mSLA, species diversity and species richness estimated as slope parameters with intercepts varyingly randomly between sites. Hence, we fitted models of the form:

$$
y_{i}=\alpha_{j(i)}+\Sigma\left(\beta_{k} * X_{i}\right)+\varepsilon_{i}
$$

where $\alpha$ specifies a random residual intercept in each study system $j$ and $\beta_{k}$ are regression slopes for each fixed effect $k$. We adopted a Bayesian modelling approach implemented in the OpenBUGS software version 3.2.1. (http://www.openbugs.info/w/). Following Gelman (2006) the between-site residual variance across the random intercepts and the overall residual variance, after having accounted for between-site variation due to fixed effects and random intercepts, were both modelled by specifying standard deviations drawn from a uniform distribution. Non-informative normal priors were specified for the individual random intercepts, the mean of the random intercepts and the regression slope parameters. Bayes $p$ values for the slope parameters were specified as a stochastic node to monitor during the model run. This simply records the number of times the estimated parameter is greater or less than zero. The mean of these values across the Monte Carlo Markov Chains (MCMC) provides the probability value (Ntzoufras 2009).

Models were generated for all combinations of untransformed NPP and the natural log of NPP predicted by $\mathrm{mSLA}$, species richness and species diversity based on square-root transformed and untransformed percentage species cover data. In addition, models were applied to explanatory and response variables with and without centring and standardising to zero mean and unit standard deviation. Quadratic terms for species richness and diversity were also tested given the possibility that NPP could increase or decrease as species diversity changed (Cardinale et al. 2011).

Outliers were identified by examining standardised residuals and testing their likely membership of the posterior predictive distribution using Bayes $p$ values for each observation (Ntzoufras 2009). We calculated a probability of observing a higher value than the observation under the posterior density as follows,

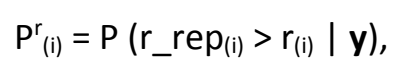


where $r_{-}$rep is the residual calculated for a predicted value drawn at random from the posterior predictive distribution and $r(i)$ is the residual of the observed value $y(i)$. Model fitting was based on three MCMC chains initialised with different parameter starting values. Convergence was assessed by inspecting trace plots (Ntzoufras 2009). Posterior estimates for all parameters of interest were based on a sample of 20000 iterations after discarding a 5000 burn-in period. The model was run for each dataset of transformed or untransformed data and the best model selected was that which minimised the overall residual variance. An overall measure of the variability explained by the covariates was based on calculation and comparison of Bayes $r^{2}$ values from a hierarchical model with covariates and random intercepts versus a linear regression model with no random intercepts. A comparison of the two values indicates the extent to which the random residual intercepts absorb additional between-site variation having already included the explanatory power of the fixed effects.

\section{Model testing}

We used the measured NPP data from the experimental study systems as a reference dataset representing each ecosystem type. The best fitting regression model was then applied to independent plant species compositional data from a national ecological surveillance program for Great Britain (Smart et al. 2003). The aim was to predict NPP values for the independent data that were comparable to the ecosystems used to build the regression model. Equivalence, in terms of ecosystem types, was established by matching the study systems against the habitat classification for the national surveillance data (Smart et al. 2003). Having extracted vegetation plots in these equivalent types, we predicted NPP and then compared these predictions against the measured experimental site data.

\section{Results}

\section{Model fitting}

Two outliers were identified (standardised residuals less than -3 and probabilities $<0.01$ of encountering lower values from the posterior predictive distribution). Both were located in the unimproved acid grassland site and coincided with high cover of bare rock and bryophytes. The model was re-run excluding these outliers. After testing all combinations of covariates, the best fitting model comprised the natural log of NPP predicted by mSLA and the Shannon-Wiener index with both calculated on square-root transformed plant cover data but no centring or standardising of explanatory or response variable (Table B2). All parameter estimates and statistics were judged robust based on the rule-of-thumb that the Bayesian MCMC error should be less than $5 \%$ of the standard deviation of the posterior density (Table B2).

There was a significant positive relationship between $\ln ($ ANPP) and mSLA and also a significant residual relationship with $\mathrm{SW}$ that was best expressed by a quadratic function where only the squared term attained significance by Bayes $p$ value (Table B2). The $r^{2}$ values for the non-hierarchical and hierarchical regression models were 0.51 and 0.89 respectively. Therefore approximately $38 \%$ of the variation in the data was explained by the random intercepts for each site after fitting the final best set of predictors.

Model testing 
Predictions for the independent test data corresponded well with the ordering of ANPP values measured in equivalent ecosystem types in the training data although with substantial residual variation unaccounted for (Figure B2). In particular, the low productivity unimproved acidic grassland site appeared to be especially different in the model training data from the sample of the same habitat type in the national dataset (Figure B2).

\section{References}

Aerts R., Berendse F. (1989) Above-ground nutrient turnover and net primary production of an evergreen and a deciduous species in a heathland ecosystem. Journal of Ecology 77, 343-356.

Cardinale B.J., Matulich, K.L., Hooper, D.U., Byrnes, J.E., Duffy, E., Gamfeldt, L., Balvanera, P., O'Connor, M.I.. (2011) The functional role of producer diversity in ecosystems. American Journal of Botany 98, 572-592.

Forrest, G.I., Smith, R.A.H. (1975) The productivity of a range of blanket bog vegetation types in the northern Pennines. Journal of Ecology 63, 173-202.

Gelman, A. (2006). Prior distributions for variance parameters in hierarchical models. Bayesian Analysis 1, 515-533.

Grime, J.P., Hodgson, J.G., Hunt, R., Thompson, K. (1995) The Electronic Comparative Plant Ecology. London. Chapman \& Hall.

Kleyer, M., Bekker, R.M., Knevel, I.C., Bakker, J.P., Thompson, K., Sonnenschein, M., Poschlod, P., van Groenandael, J.M., Klimes, L., Klimesova, J., Klotz, S., Rusch, G.M., Hermy, M., Adriaens, D., Boedeltje, G., Bossuyt, B., Danneman, A., Edndels, P., Gotzenberger, L., Hodgsno, J.G., Jackel, A.K., Kuhn, I., Kunzmann, D., Ozinga, W.A., Romermann, C., Stadler, M., Schlegelmilch, J., Steendham, H.J., Tackenberg, O., Wilmann, B., Cornelissen, J.H.C., Eriksson, O., Granier, E., Peco, B. (2008) The LEDA traitbase: a database of life-history traits of the NW European flora. Journal of Ecology 96, 1266-1274.

McNaughton, S.J., Milchunas, D.G., Frank, D.A. (1996) How can net primary productivity be measured in grazing ecosystems? Ecology 77, 974-977.

Ntzoufras, I. (2009) Bayesian Modelling Using WinBUGS. Wiley Series in Computational Statistics. John Wiley \& Sons, Inc. New Jersey.

Perkins, D.F., Jones, V., Millar, R.O., Neep, P. (1978) Primary production, mineral nutrients and litter decomposition in the grassland ecosystem. In: Production Ecology of British Moors and Montane Grasslands (eds Heal, O.W., Perkins, D.F.), pp. 304- 332. Springer-Verlag, Berlin.

Smart, S.M., Clarke, R.T., van de Poll, H.M., Robinson, E.J., Shield, E.R., Bunce, R.G.H., Maskell, L.C. (2003) National-scale vegetation change across Britain; an analysis of sample-based surveillance data from the Countryside Surveys of 1990 and 1998. Journal of Environmental Management 67, 239-254.

Wright, I.J., Reich, P.B., Westoby, M., Ackerly, D.D., Baruch, Z., Bongers, F., Cavender-Bares, J., Chapin, T., Cornelissen, J.H.C., Diemer, M., Flexas, J., Garnier, E., Groom, P.K., Gulias, J., Hikosaka, K., Lamont, B.B., Lee, T., Lee, W., Lusk, C., Midgely, J.J., Navas, M.L., Niinements, U., Oleksyn, J., Osada, N., Poorter, H., Poot, P., Prior, L., Pyankov, V.I., Roumet, C., Thomas, S.C, Tjoelker, M.G., Veneklaas, E.J., Villar, R. (2004) The world-wide leaf economics spectrum. Nature 428, 821-827. 
Figure B1. Map showing the location of the experimental sites within which paired above-ground ANPP and plant species compositional measurements were made.

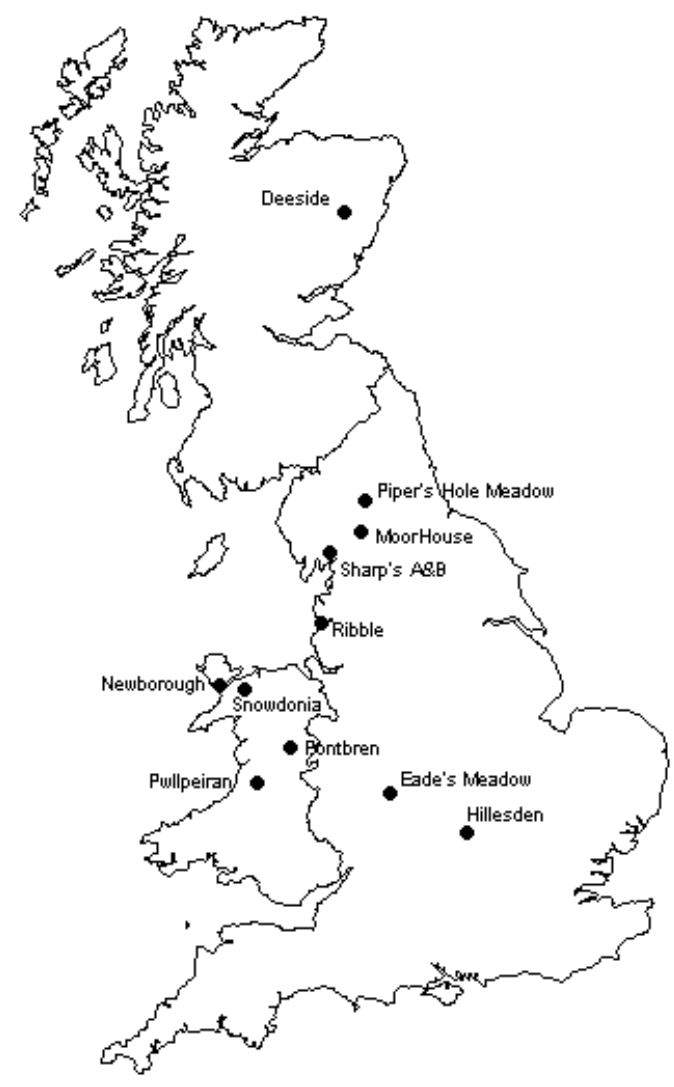

Table B1. Parameters and descriptive statistics for the posterior predictive distribution of the best model for estimating $\ln (\mathrm{NPP})$, ( $\mathrm{n}=95$ plots across 14 experimental study systems). Significance by Bayes $p$ values indicated for each model term.

\begin{tabular}{|l|r|r|r|r|r|r|}
\hline & Mean & \multicolumn{1}{|l|}{ SD } & $\begin{array}{l}\text { Monte } \\
\text { Carlo } \\
\text { error }\end{array}$ & 2.5\%tile & median & 97.5\%tile \\
\hline mSLA (<0.0001) & 0.0352 & 0.007846 & $2.88 \mathrm{E}-04$ & 0.02004 & 0.03508 & 0.05047 \\
\hline Shannon-Weiner (ns) & -0.4079 & 0.2589 & 0.01193 & -0.9304 & -0.4073 & 0.08218 \\
\hline (Shannon-Weiner)^ $2(<0.05)$ & 0.1194 & 0.07169 & 0.003243 & -0.01869 & 0.1192 & 0.2652 \\
\hline & & & & & & \\
\hline Mean of random intercepts & 5.633 & 0.2777 & 0.009511 & 5.107 & 5.626 & 6.193 \\
\hline
\end{tabular}

Figure B2. An independent test of observed versus predicted InNPP $\left(\mathrm{gm} \mathrm{m}^{-2} \mathrm{yr}^{-1}\right)$ using subsets of vegetation plots from the GB Countryside Survey in 1998. Observed InNPP in the model training data 
was compared with InNPP predicted from the empirical model and applied to all plots from the survey that were referable to the same ecosystem types as those represented by the experimental study systems. Each point represents the mean +/- 1 se.

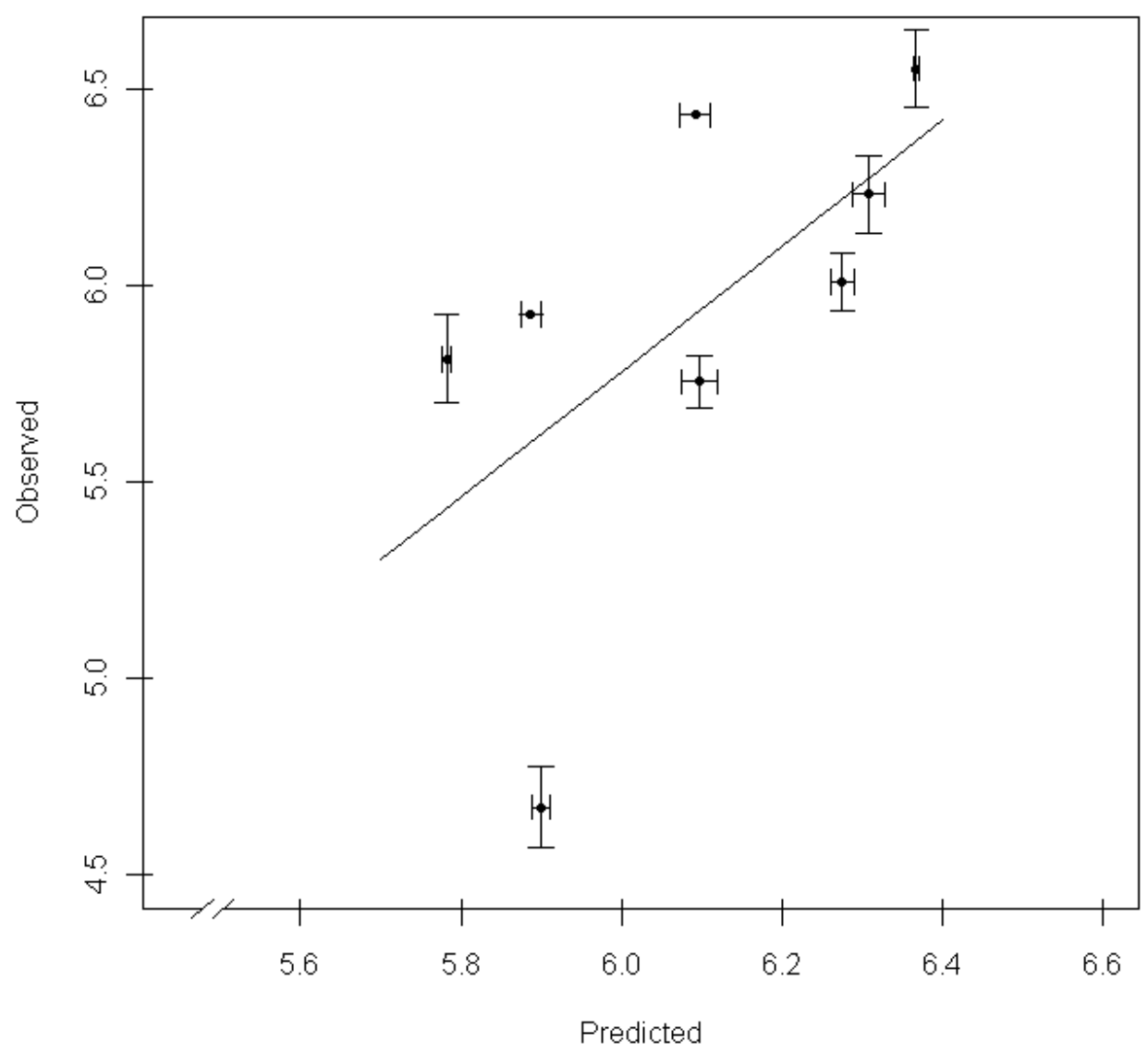


Table B2. Datasets used to model ANPP in terms of plant species composition. UK Biodiversity Action Plan habitat names were taken from the online list

(UK_list_of_Priority_Habitats_and_Species_for_download_v1.4 2010 2505.xls) at

http://jncc.defra.gov.uk/page-5436. Dominant plant species are either bryophytes (b), trees (t), grasses (g), sedges (s), dwarf shrub (ds) or forbs (f).

\begin{tabular}{|c|c|c|c|c|c|c|}
\hline $\begin{array}{l}\text { Experimental } \\
\text { site }\end{array}$ & $\begin{array}{l}\text { Number of } \\
\text { paired ANPP } \\
\text { and SLA } \\
\text { measurements }\end{array}$ & $\begin{array}{l}\text { UK } \\
\text { Biodiversity } \\
\text { Action Plan } \\
\text { Broad (B) } \\
\text { or Priority } \\
\text { (P) Habitat } \\
\text { type }\end{array}$ & $\begin{array}{l}\text { FAO soil } \\
\text { group }\end{array}$ & $\begin{array}{l}\text { Mean } \\
\text { soil } \\
\text { pH } \\
\text { (+/se) }\end{array}$ & $\begin{array}{l}\text { Dominant plant } \\
\text { species }\end{array}$ & $\begin{array}{l}\text { Management } \\
\text { regime }\end{array}$ \\
\hline Newborough & 9 & $\begin{array}{l}\text { Neutral } \\
\text { grassland } \\
\text { (B) }\end{array}$ & Cambisol & $\begin{array}{l}7.67 \\
(0.05)\end{array}$ & $\begin{array}{l}\text { Agrostis } \\
\text { capillaris L. (g) } \\
\text { Arrhenatherum } \\
\text { elatius (g) } \\
\text { Hylocomium } \\
\text { splendens } \\
\text { (Hedw.) } \\
\text { Schimp. (b) }\end{array}$ & $\begin{array}{l}\text { Low intensity } \\
\text { rabbit and } \\
\text { cattle } \\
\text { grazing. }\end{array}$ \\
\hline Pontbren & 8 & $\begin{array}{l}\text { Improved } \\
\text { grassland } \\
\text { (B) }\end{array}$ & $\begin{array}{l}\text { Gleysol } \\
\& \\
\text { Cambisol }\end{array}$ & $\begin{array}{l}5.46 \\
(0.09)\end{array}$ & $\begin{array}{l}\text { Holcus lanatus } \\
\text { L. }(g) \\
\text { Agrostis } \\
\text { stolonifera L. } \\
\text { (g) } \\
\text { Lolium perenne } \\
\text { L. }(g)\end{array}$ & $\begin{array}{l}\text { High intensity } \\
\text { sheep } \\
\text { grazing. }\end{array}$ \\
\hline Pwllpeiran & 7 & $\begin{array}{l}\text { Acid } \\
\text { grassland } \\
\text { (B) }\end{array}$ & Podzol & $\begin{array}{l}4.06 \\
(0.02)\end{array}$ & $\begin{array}{l}\text { Nardus stricta } \\
\text { L. (g) } \\
\text { Carex binervis } \\
\text { Sm. (s) } \\
\text { Vaccinium } \\
\text { myrtillus L. (ds) }\end{array}$ & $\begin{array}{l}\text { Moderate } \\
\text { intensity } \\
\text { sheep } \\
\text { grazing. }\end{array}$ \\
\hline Ribble & 6 & $\begin{array}{l}\text { Coastal and } \\
\text { Floodplain } \\
\text { Grazing } \\
\text { Marsh (P) }\end{array}$ & Fluvisol & $\begin{array}{l}6.35 \\
(0.17)\end{array}$ & $\begin{array}{l}\text { Festuca rubra L. } \\
\text { (g) } \\
\text { Elytrigia repens } \\
\text { (L.) Desv. (g) } \\
\text { Agrostis } \\
\text { stolonifera }(g)\end{array}$ & $\begin{array}{l}\text { Ungrazed or } \\
\text { very low } \\
\text { intensity } \\
\text { cattle } \\
\text { grazing. }\end{array}$ \\
\hline Moorhouse & 5 & $\begin{array}{l}\text { Blanket bog } \\
\text { (P) }\end{array}$ & Histosol & $\begin{array}{l}4.17 \\
(0.01)\end{array}$ & $\begin{array}{l}\text { Calluna vulgaris } \\
\text { (L.) Hull (ds) } \\
\text { Empetrum } \\
\text { nigrum L. (ds) } \\
\text { Eriophorum } \\
\text { vaginatum L. (s) }\end{array}$ & $\begin{array}{l}\text { Very low } \\
\text { intensity } \\
\text { sheep } \\
\text { grazing. }\end{array}$ \\
\hline Snowdonia & 1 & $\begin{array}{l}\text { Upland } \\
\text { Calcareous } \\
\text { grassland }\end{array}$ & Leptosol & $\begin{array}{l}6.80 \\
(0.78)\end{array}$ & $\begin{array}{l}\text { Agrostis } \\
\text { capillaris (g) } \\
\text { Festuca ovina L. }\end{array}$ & $\begin{array}{l}\text { Low intensity } \\
\text { sheep grazing }\end{array}$ \\
\hline
\end{tabular}




\begin{tabular}{|c|c|c|c|c|c|c|}
\hline $\begin{array}{l}\text { Experimental } \\
\text { site }\end{array}$ & $\begin{array}{l}\text { Number of } \\
\text { paired ANPP } \\
\text { and SLA } \\
\text { measurements }\end{array}$ & $\begin{array}{l}\text { UK } \\
\text { Biodiversity } \\
\text { Action Plan } \\
\text { Broad (B) } \\
\text { or Priority } \\
\text { (P) Habitat } \\
\text { type } \\
\end{array}$ & $\begin{array}{l}\text { FAO soil } \\
\text { group }\end{array}$ & $\begin{array}{l}\text { Mean } \\
\text { soil } \\
\text { pH } \\
\text { (+/se) }\end{array}$ & $\begin{array}{l}\text { Dominant plant } \\
\text { species }\end{array}$ & $\begin{array}{l}\text { Management } \\
\text { regime }\end{array}$ \\
\hline & & $(\mathrm{P})$ & & & $\begin{array}{l}\text { (g) } \\
\text { Rhytidiadelphus } \\
\text { squarrosus } \\
\text { (Hedw.) } \\
\text { Warnst. (b) }\end{array}$ & \\
\hline Sharp's A & 6 & $\begin{array}{l}\text { Improved } \\
\text { grassland } \\
\text { (B) }\end{array}$ & Gleysol & $\begin{array}{l}6.00 \\
(0.07)\end{array}$ & $\begin{array}{l}\text { Lolium perenne } \\
\text { (g) }\end{array}$ & $\begin{array}{l}\text { Intensive } \\
\text { grass silage } \\
\text { production } \\
\text { and cattle } \\
\text { grazing }\end{array}$ \\
\hline Sharp's B & 6 & $\begin{array}{l}\text { Improved } \\
\text { grassland } \\
\text { (B) }\end{array}$ & Gleysol & $\begin{array}{l}6.30 \\
(0.25)\end{array}$ & $\begin{array}{l}\text { Lolium perenne } \\
\text { (g) } \\
\text { Poa trivialis (g) }\end{array}$ & $\begin{array}{l}\text { Intensive } \\
\text { grass silage } \\
\text { production } \\
\text { and cattle } \\
\text { grazing }\end{array}$ \\
\hline $\begin{array}{l}\text { Eades } \\
\text { Meadow }\end{array}$ & 5 & $\begin{array}{l}\text { Lowland } \\
\text { Hay } \\
\text { Meadow (P) }\end{array}$ & Cambisol & $\begin{array}{l}6.23 \\
(0.60)\end{array}$ & $\begin{array}{l}\text { Agrostis } \\
\text { capillaris (g) } \\
\text { Cynosurus } \\
\text { cristatus L. (g) } \\
\text { Rhinanthus } \\
\text { minor L. (f) }\end{array}$ & $\begin{array}{l}\text { Low intensity } \\
\text { Spring and } \\
\text { Autumn } \\
\text { cattle grazing } \\
\text { and Summer } \\
\text { hay cut }\end{array}$ \\
\hline Piper's Hole & 6 & $\begin{array}{l}\text { Upland Hay } \\
\text { Meadow (P) }\end{array}$ & Cambisol & $\begin{array}{l}5.87 \\
(0.15)\end{array}$ & $\begin{array}{l}\text { Lolium perenne } \\
\text { (g) } \\
\text { Geranium } \\
\text { sylvaticum L. (f) } \\
\text { Sanguisorba } \\
\text { officinalis L. (f) }\end{array}$ & $\begin{array}{l}\text { Low intensity } \\
\text { Spring and } \\
\text { Autumn } \\
\text { sheep and } \\
\text { cattle grazing } \\
\text { and Summer } \\
\text { hay cut }\end{array}$ \\
\hline Deeside & 19 & $\begin{array}{l}\text { Upland } \\
\text { Birchwoods } \\
\text { (P) }\end{array}$ & Podzol & $\begin{array}{l}4.21 \\
(0.98)\end{array}$ & $\begin{array}{l}\text { Betula pendula } \\
\text { Roth (t) } \\
\text { Deschampsia } \\
\text { flexuosa (L.) } \\
\text { Trin. (g) } \\
\text { Rhytidiadelphus } \\
\text { triquetrus } \\
\text { (Hedw.) } \\
\text { Warnst. (b) }\end{array}$ & $\begin{array}{l}\text { Ten sites } \\
\text { ungrazed. } \\
\text { The } \\
\text { remainder } \\
\text { lightly to } \\
\text { moderately } \\
\text { cattle and } \\
\text { sheep grazed. }\end{array}$ \\
\hline
\end{tabular}

